
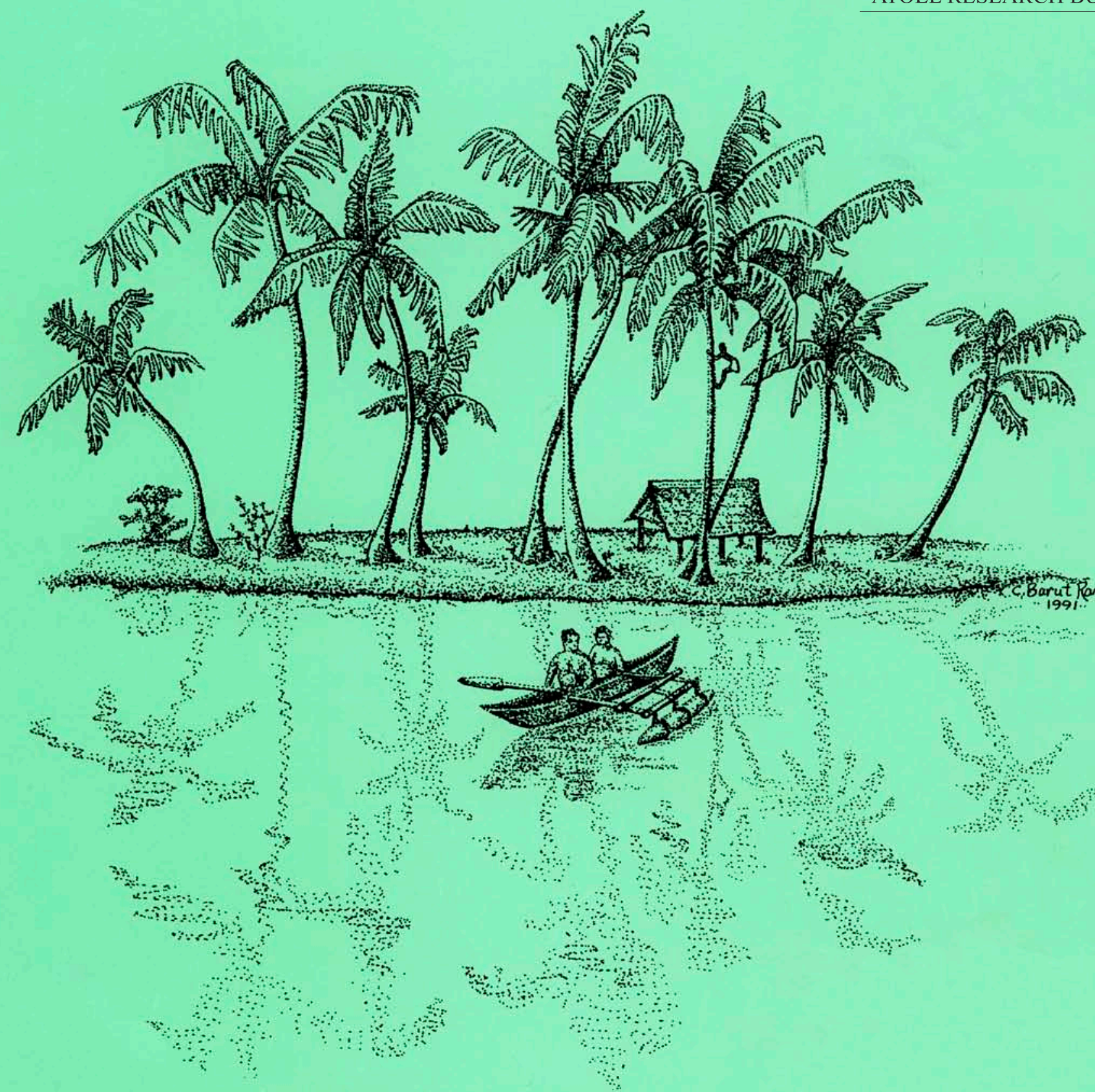

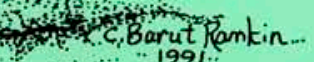

CHARACTERIZATION OF CORAL COMMUNITIES AT

WAKE ATOLL IN THE REMOTE CENTRAL PACIFIC OCEAN

Jean C. Kenyon, Victor Bonito, and Casey B. Wilkinson

Smithsonian Institution

Scholarly Press

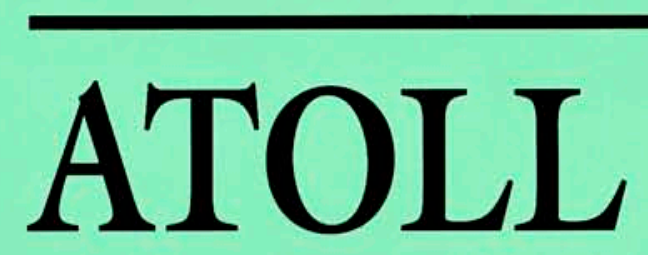

RESEARCH

BULLETIN 


\section{CHARACTERIZATION OF CORAL COMMUNITIES AT WAKE ATOLL IN THE REMOTE CENTRAL PACIFIC OCEAN}

Jean C. Kenyon, Victor Bonito, and Casey B. Wilkinson

Atoll Research Bulletin No. 600 • 30 December 2013

Scholarly Press 
All statements made in papers published in the Atoll Research Bulletin are the sole responsibility of the authors and do not necessarily represent the views of the Smithsonian Institution or of the editors of the Bulletin. Articles submitted for publication in the Atoll Research Bulletin should be original papers and must be made available by authors for open access publication. Manuscripts should be consistent with the "Author Formatting Guidelines for Publication in the Atoll Research Bulletin." All submissions to the Bulletin are peer reviewed and, after revision, are evaluated prior to acceptance and publication through the publisher's open access portal, Open SI (http://opensi.si.edu).

Published by SMITHSONIAN INSTITUTION SCHOLARLY PRESS

P.O. Box 37012, MRC 957

Washington, D.C. 20013-7012

www.scholarlypress.si.edu

The rights to all text and images in this publication are owned either by the contributing authors or third parties. Fair use of materials is permitted for personal, educational, or noncommercial purposes. Users must cite author and source of content, must not alter or modify the content, and must comply with all other terms or restrictions that may be applicable. Users are responsible for securing permission from a rights holder for any other use.

ISSN: 0077-5630 (online) 


\title{
CHARACTERIZATION OF CORAL COMMUNITIES AT WAKE ATOLL IN THE REMOTE CENTRAL PACIFIC OCEAN
}

\author{
JEAN C. KENYON ${ }^{1}$, VICTOR BONITO² ${ }^{2}$, and CASEY B. WILKINSON ${ }^{3}$
}

\begin{abstract}
Little published or unpublished information exists concerning the benthic community structure or coral fauna at Wake Atoll in the Central Pacific. Here, we apply multivariate statistical analyses to data acquired in 2005 from several complementary survey methods that operate at different scales of spatial and taxonomic resolution to characterize the coral communities in the fore-reef habitat, which is further stratified by geographic sector and depth zone. Both broad-scale towed-diver surveys and site-specific photoquadrat surveys revealed high dissimilarity in overall benthic composition between the northeast and southwest sectors. Coral cover in the northeast sector is more than 2.5 times greater than in the southwest sector; encrusting and massive growth forms dominate in the northeast sector while encrusting and digitate growth forms dominate in the southwest sector. Coral cover and colony abundances are less dominated by a few key genera in the northeast than in the southwest sector, though the genera Montipora, Pocillopora, and Favia are the most numerically abundant taxa in both sectors. Octocorals account for more than $25 \%$ of the total coral cover in the northeast sector but less than $5 \%$ of the total coral cover in the southwest sector. The deep northeast stratum showed among the highest diversity of growth forms as well as the highest total coral cover, octocoral cover, and coralline algal cover. We provide a list of 101 anthozoan and hydrozoan corals observed at Wake Atoll during survey activities since the year 1979. Five scleractinian species at Wake are on the IUCN Red List of Threatened Species $^{\mathrm{TM}}$. The 80 taxa with well-established species names contain components from the Mariana Islands, northern Marshall Islands, and Hawaiian Islands, but show the closest resemblance to the Mariana Islands. Our spatially widespread surveys that generate independent metrics of benthic cover and coral abundance collectively provide the most comprehensive description of coral communities at Wake Atoll produced to date and also provide an important record by which to monitor the response of this community to changing ocean conditions.
\end{abstract}

\section{INTRODUCTION}

Wake Atoll $\left(19^{\circ} 17^{\prime} \mathrm{N}, 166^{\circ} 37^{\prime} \mathrm{E}\right)$ is a small closed atoll in the central Pacific that is extremely isolated from other shallow coral reefs. It lies $2260 \mathrm{~km}$ northeast of Guam $\left(13^{\circ} 25^{\prime} \mathrm{N}, 144^{\circ} 47^{\prime} \mathrm{E}\right)$ in the southern Mariana Islands, $1900 \mathrm{~km}$ southwest of Kure Atoll $\left(28^{\circ} 25^{\prime} \mathrm{N}, 178^{\circ} 20^{\prime} \mathrm{W}\right)$, the nearest reef in the Hawaiian Archipelago, and $546 \mathrm{~km}$ northwest of Bok-ak (Taongi) $\left(14^{\circ} 39^{\prime} \mathrm{N}, 168^{\circ} 58^{\prime} \mathrm{E}\right)$, the nearest reef in the Marshall Islands. The emergent land consists of three low-lying coral islets (Peale, Wake, and Wilkes; Figure 1) that border a shallow lagoon. A reef flat, over which most water exchange takes place between the open ocean and the lagoon, comprises the western side of the atoll (Lobel and Lobel, 2008). The atoll's longest axis extends $\sim 8 \mathrm{~km}$ in a southeast-northwest direction, with prevailing winds arriving from the east-northeast.

\footnotetext{
${ }^{1}$ Hawaiian and Pacific Islands National Wildlife Refuge Complex, U.S. Fish and Wildlife Service, 300 Ala Moana Blvd., Honolulu, Hawai`i 96850, USA; Jean_Kenyon@fws.gov

${ }^{2}$ Reef Explorer Fiji Ltd., Box 183, Korolevu, Fiji Islands

${ }^{3}$ Coral Reef Ecosystem Division, NOAA Pacific Islands Fisheries Science Center, 1125B Ala Moana Blvd., Honolulu, Hawai i 96813
} 


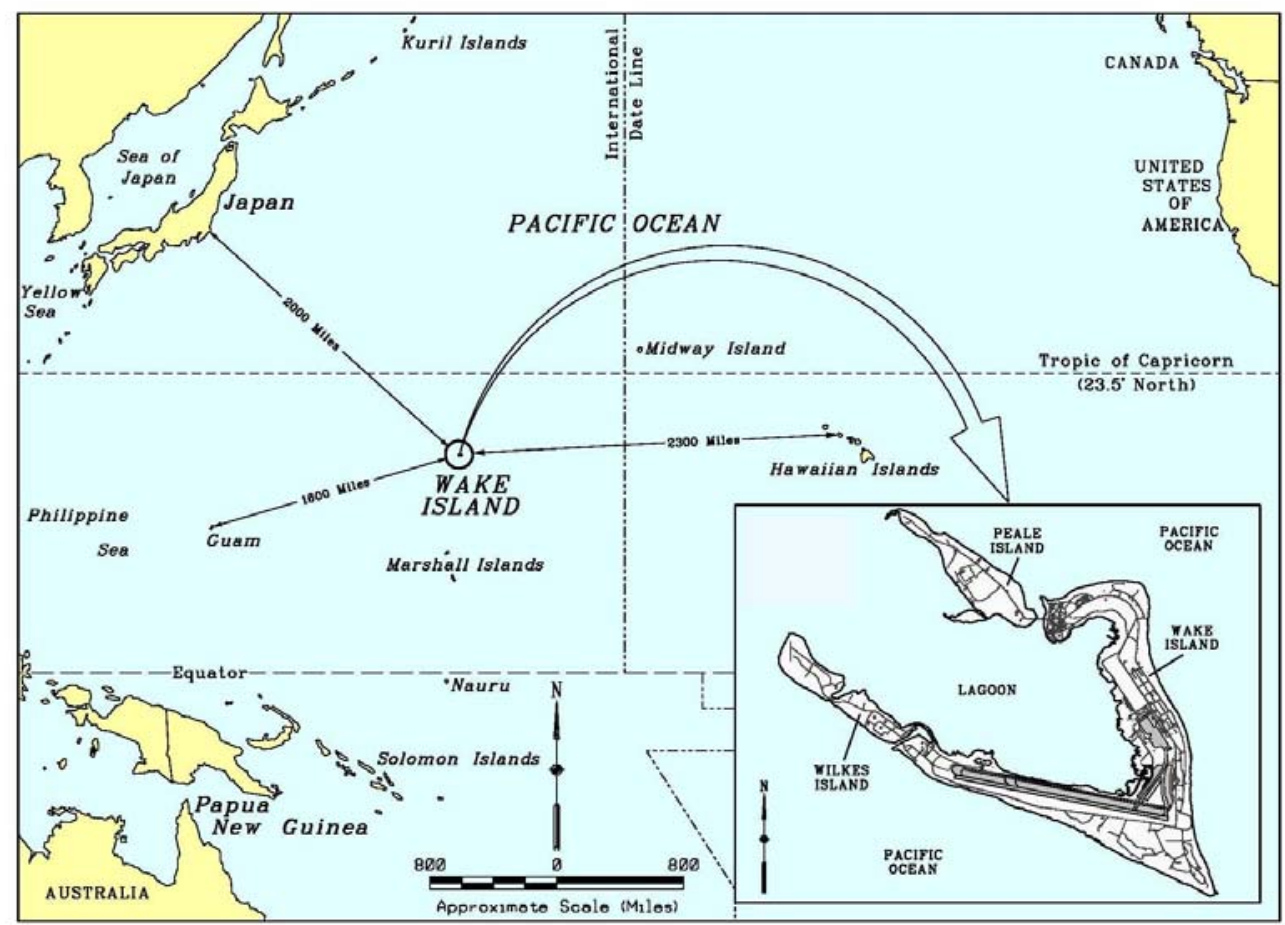

Figure 1. Location of Wake Atoll in the central Pacific

The first visitors to Wake Atoll were probably early navigators from the Marshall Islands who periodically visited the atoll to hunt sea turtles and birds. In 1568 the Spanish explorer Mendaña was the first European to report sighting the atoll (Bryan, 1959), which was later named for the British sea captain William Wake who documented its location in 1796 (Lobel and Lobel, 2008) The U.S. Exploring Expedition, which visited in December 1841 under the leadership of Lt. (later Commodore) Charles Wilkes, provided the first surveys, maps, and detailed descriptions of the atoll, noting that "the reef around this island is very small in extent" (Wilkes, 1844). Wake was formally claimed by the United States in 1898 during the Spanish American War. During the 1923 Tanager Expedition led by Honolulu's Bernice P. Bishop Museum, the southwestern islet was named for Lt. Wilkes and the northwestern island for Titian Peale, a naturalist and artist who accompanied the U.S. Exploring Expedition. In 1934 the U.S. Navy was given responsibility for Wake and a military base was constructed in early 1941. Attacked and captured by the Japanese in December 1941, the atoll remained in Japanese possession until their surrender in 1945. Following World War II, Wake came under the administration of the U.S. Army Space and Missile Defense Command, serving as a support facility for testing intermediate-range target missiles. On January 6, 2009, President George W. Bush established the Pacific Remote Islands Marine National Monument, which includes the emergent and submerged lands and waters extending 50 nautical miles (nmi) from the mean low water line at Wake and 6 other U.S.-administered islands and atolls in the Pacific. The land areas at Wake remain under the jurisdiction of the U.S. Air Force, but the waters from 0 to $12 \mathrm{nmi}$ are protected as a unit of the National Wildlife Refuge System. Fishery-related activities seaward from the 12-nmi refuge boundaries out to the 50 -nmi monument boundary are managed by the National Oceanic and Atmospheric Administration (NOAA).

Knowledge of the shallow water coral fauna of Wake Atoll previously has been limited to observations contained in an unpublished list (J. Maragos, pers. comm.) and an interagency government report (USFWS, 1999). Although coral specimens were collected from Wake during the 1923 Tanager Expedition (Gregory, 1924; Olson, 1996), no publication treating their taxonomic analysis was ever produced as was done for other marine invertebrate groups (Edmondson et al., 1925). Maragos visited the 
atoll in May 1979 and compiled a list including 31 scleractinian and hydrozoan species from 14 genera based on qualitative snorkel surveys at five locations, two along the shallow south fore reef, two on the northern reef flat, and one in the channel between Peale and Wake Islands (Figure 2). In June 1998, M. Molina representing the U.S. Fish and Wildlife Service compiled a list including 41 species from 22 scleractinian and hydrozoan genera based on scuba surveys at six sites at a depth of $\sim 10 \mathrm{~m}$ on the forereef slope along the southern exposure of the atoll (Figure 2). Together their records totaled 52 species from 25 genera. In October 2005, reef assessment and monitoring activities were initiated at Wake Atoll by the NOAA, Pacific Islands Fisheries Science Center's Coral Reef Ecosystem Division as part of a larger multidisciplinary effort to assess and monitor coral reef ecosystems in the U.S. Pacific Islands (Brainard et al., 2008). Broad-scale towed-diver surveys were initiated to provide a spatial assessment of the composition and condition of shallow-water benthic habitats coupled with site-specific surveys to assess species composition, abundance, percent cover, size distribution, and general health of salient benthic organisms including corals.

The main aims of the present study are to (1) describe the community structure of the shallow-water $(<29 \mathrm{~m})$ corals in the fore-reef habitat at Wake Atoll, based on broad-scale and site-specific quantitative surveys conducted in 2005, and (2) provide a species list of anthozoan and hydrozoan corals, compiling records from the suite of surveys conducted from 1979 to 2005, and (3) assess species overlap of Wake corals with the Mariana, northern Marshall, and Hawaiian Islands. In describing community structure, we applied survey methods that operate at different scales of spatial and taxonomic resolution to generate independent metrics of community abundance. For each method and metric we applied statistical analyses developed for use with multivariate ecological data to determine spatial differences and their underlying taxonomic basis. Our study, which presents a detailed and spatially widespread multivariate analysis of the coral communities in the fore-reef habitat at Wake Atoll, serves as an important baseline from the early years of the twenty-first century, which can serve as an important and useful standard for future generations of scientists, managers, and other stakeholders.

\section{MATERIALS AND METHODS}

\section{Benthic Surveys}

Towed-diver surveys were conducted in 2005 (18-21 October) according to the methods of Kenyon et al. (2006a) in the fore-reef slope habitat (Figure 2). Modifications to these methods included the use of a digital still camera (Canon EOS-10D, EF 20-mm lens) in a customized housing with strobes to photograph the benthos automatically at 15-sec intervals. Site-specific belt-transect surveys to assess coral colony abundance and size class were conducted by a single diver (J. Kenyon) from 18 to 21 October 2005 according to the general methods described by Maragos et al. (2004) for Rapid Ecological Assessments. Twelve sites (11-18 m depth) were surveyed on the fore-reef slope and one (2-3 m depth) in the western lagoon (Figure 2). Two $25 \mathrm{x} 1 \mathrm{~m}$ transect belts were surveyed at each site except for the lagoon site, where transects were widened to 25 x 2 m due to low colony density. Each coral whose colony center fell within a 0.5 -m-wide strip on each side of the lines (1-m-wide for the lagoon site) was classified to genus and its maximum diameter binned into one of six size classes (Mundy, 1996): 0-5 cm, 5-10 cm, 10-20 cm, 20-40 cm, 40-80 cm, or 80-160 cm. To determine percent cover of benthic components, $12(35 \mathrm{~cm}$ x $50 \mathrm{~cm}$ ) photoquadrats were concurrently photographed with a Sony DSC P-9 digital still camera with spatial reference to the same two 25-m transect lines: three photoquadrats at randomly selected points along each transect and three at points $3 \mathrm{~m}$ perpendicular from each random point in the direction of shallower water (i.e., 6 photoquadrats per transect; Preskitt et al., 2004; Vroom et al., 2005). Locations of site-specific surveys were determined on the basis of (1) maximizing spatial coverage along the fore reef within the allotted number of survey days; (2) establishing depths that allowed three dives per day per diver; (3) working within constraints imposed by other ship-supported operations; and (4) sea conditions. 


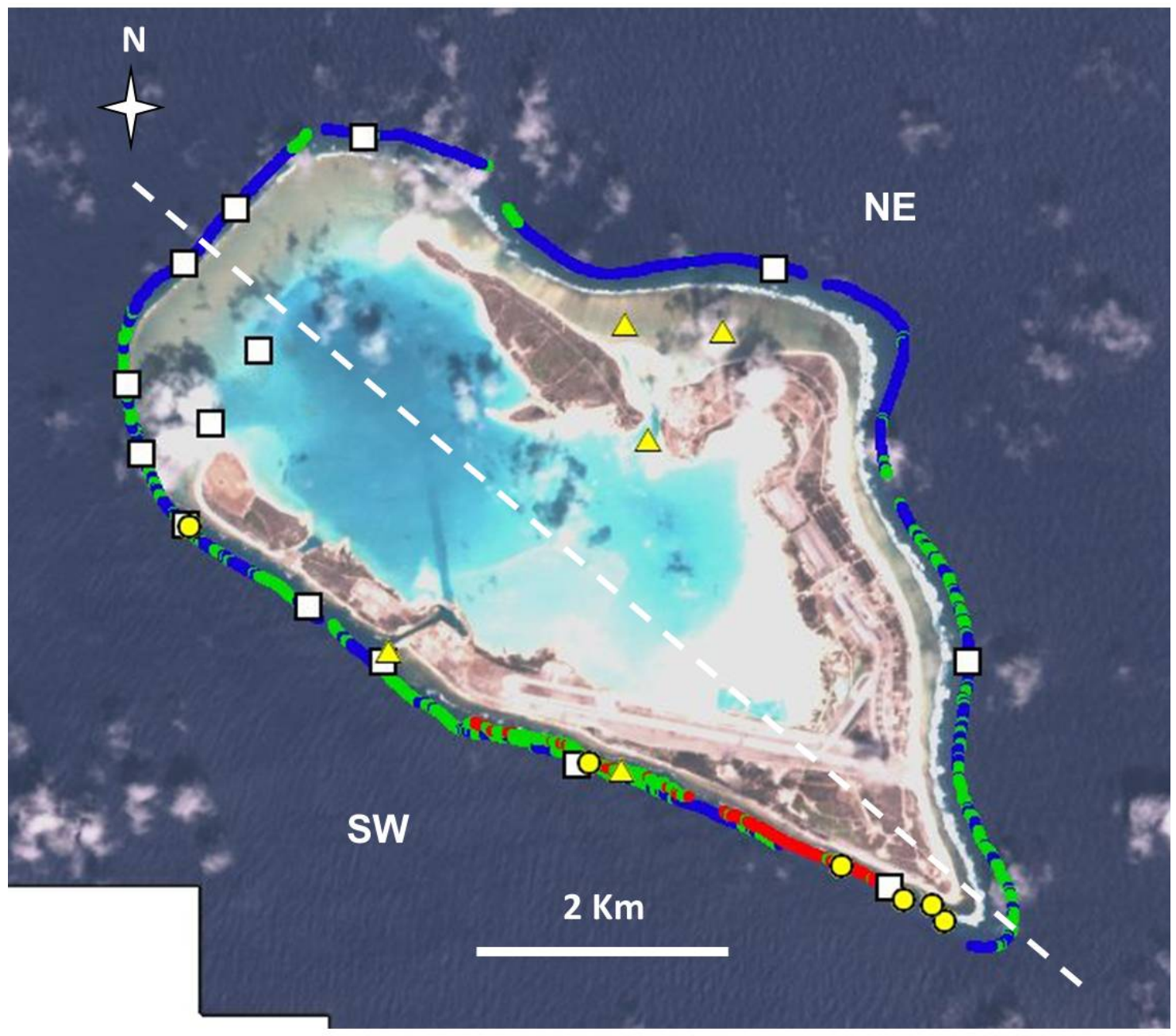

\section{Site-specific surveys}

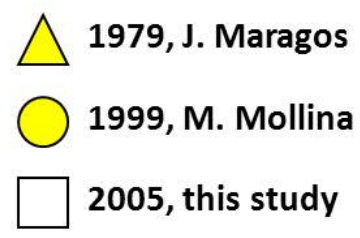

Towed-diver surveys

Shallow $(<9.1 \mathrm{~m})$

Moderate (9.1-18.2 m)

Deep (18.2-28.5 m)

Figure 2. Location of towed-diver and site-specific surveys at Wake Atoll. Tow track lines are color coded according to the depth zone of the photographs sampled for image analysis.

Species lists of anthozoan and hydrozoan corals were compiled in situ by the lead authors in the vicinity of the transect lines at each site, and at an additional reef flat site north of Wilkes Island (Figure 2). Photographs were taken in situ for most species to assist in verifying taxonomic assignments and resolving uncertainties using Veron (2000) and Randall and Myers (1983), with revisions to the latter in Randall (2003). Samples were collected of 62 scleractinian, 1 hydrozoan, 4 alcyonarian, and 1 zoanthid taxa, which were examined with a dissecting microscope to additionally assist in identifications. Samples were tagged, numbered, linked to a photo library and data base with collection information, and deposited 
in the Florida Museum of Natural History coral collection curated by Gustav Paulay (catalog numbers 4073-4107 and 5900-5977). The resulting species list was integrated with lists previously compiled by J. Maragos (unpublished data, 1979) and by M. Molina (USFWS, 1999). To examine the geographic affinities of Wake corals, taxa with well-established species names were compared to lists from Hawai $i$ (Fenner, 2005), the Mariana Islands (Randall, 2003), and the northern Marshall Islands (Bok-ak, Pikaar, Tōke, Wōtte, Rondik, Ādkup, and Jemo; Maragos, 1994).

\section{Data Extraction and Analysis}

Digital photographs from towed-diver surveys were sampled at 30-sec intervals and quantitatively analyzed for benthic percent cover by a single analyst (C. Wilkinson), using point-count software (Coral Point Count with Excel Extension; Kohler and Gill, 2006) and using 50 stratified random points per frame. Benthic classification categories included hard coral, soft coral, macroalgae, coralline red algae, noncoral macroinvertebrates, sand, rubble, and pavement. Hard corals were subclassified morphologically as branching, digitate, encrusting, massive, free-living (mushroom) and plate-like. Laser-projected dots used to calibrate image size did not appear on photographic imagery because of mechanical problems; consequently, scaling data from imagery recorded throughout the Northwestern Hawaiian Islands with the same methods (Kenyon et al., 2006b, 2007a, 2007b, 2008a, 2008b) were used to calculate average benthic area in captured frames. Survey distances were calculated using a global positioning system (GPS) and ArcView GIS 3.3. The depth of each captured frame was determined by matching the time stamp of the image with that of temperature/pressure data recorded by an SBE 39 recorder (Sea-Bird Electronics, Inc.) mounted on the habitat towboard. For statistical analysis, each frame was categorized in one of six strata defined a priori by the concatenation of two factors: sector (northeast or southwest, where a line between the southeast vertex of the island and the midpoint of the northwest-facing reef slope was used to separate northeast from southwest) and depth zone (shallow $[<9.1 \mathrm{~m}]$, moderate [9.1-18.2 m], or deep [18.2-28.5 $\mathrm{m}])$. Thus, frames from towed-diver surveys that spanned more than one sector or depth zone were parsed into separate strata using the time stamp that linked GPS position and depth to recorded imagery. No frames were acquired from shallow depths in the northeast sector, resulting in data for only five of the six defined strata.

Photoquadrats were analyzed for benthic percent cover by a single analyst (J. Kenyon), using Coral Point Count with Excel Extensions (Kohler and Gill, 2006) and using 50 stratified random points per digital image. Anthozoans were identified to genus, while algae were categorized as Halimeda, other macroalgae, and coralline red algae. Additional benthic classification categories included noncoral macroinvertebrates, sand, rubble, and pavement. Site locations and tracks of towed-diver surveys georeferenced with nondifferentially corrected GPS units (Garmin ${ }^{\circledR}$ model 12) were mapped using ArcView GIS 3.3.

All statistical analyses were conducted using PRIMER-E®, version 6 (Clarke and Warwick, 2001; Clarke and Gorley, 2006). For towed-diver surveys, benthic percent cover data from each survey frame were treated as individual replicates within a stratum. Two separate matrices were created. One matrix included percent cover data of all benthic categories to examine differences in overall benthic composition among the strata. A second matrix included only coral data, standardized as percent of total coral cover, to examine differences in relative abundance of coral growth forms among the strata. Squareroot transformations were performed on the data matrices to lessen the influence of prevalent benthic components and increase the weight of rare benthic components, and Bray-Curtis resemblance matrices were created from transformed data. To explore spatial distributional patterns, one-way analyses of similarity (ANOSIM; maximum permutations $=9999)$ were conducted on each matrix to determine if differences existed among the five sampled fore-reef strata. When ANOSIM detected global differences, $R$ values from pairwise tests were examined to determine where major differences existed. SIMPER (similarity percentages routine) analyses using nontransformed data explored the contribution of individual benthic components or coral groups to the dissimilarities. 
To visually depict the relationships of strata to each other based on benthic community structure, data were averaged by stratum, and a Bray-Curtis similarity matrix (with square-root transformations) was generated to create a cluster diagram (group average cluster mode) and nonmetric multidimensional scaling (nMDS) ordinations (number of restarts $=50$ ).

Site-specific photoquadrat and coral belt-transect surveys were conducted within the moderate-depth zone at the 12 fore-reef sites and in shallow depths $(2-3 \mathrm{~m})$ at the single lagoon site. Percent cover data from each photoquadrat image were treated as individual replicates within sites. Treatment of photoquadrat percent cover data including all benthic categories was similar to that described for toweddiver survey percent cover data. From a matrix including only coral data, ranked cumulative abundance ( $k$-dominance) curves were constructed from nonstandardized data, and ANOSIM was conducted on a matrix of distances generated by DOMDIS (dominance distance) between the dominance curves in the two fore-reef sectors. To explore the relative abundance of coral genera using the numbers of colonies rather than percent cover as a metric, $k$-dominance curves were constructed from nonstandardized colony count data, and ANOSIM was conducted on a separate matrix of distances generated by DOMDIS between the $k$-dominance curves in the two fore-reef sectors. SIMPER analysis on nontransformed data explored average similarities and dissimilarities among samples and the contribution of individual taxa to the dissimilarities. Neither photoquadrat nor colony count data from the lagoon patch reef were included in statistical analyses because the single site surveyed likely does not adequately represent the lagoon.

To examine differences in size-class structure among fore-reef sectors of the two most numerically abundant genera, Pocillopora and Montipora, the number of colonies of each genus was standardized and then cumulated at each site, and a resemblance matrix based on Euclidean distance was created for each genus. A one-way ANOSIM was conducted for each genus to determine if the size-class distributions differed between fore-reef sectors.

\section{RESULTS}

\section{Towed-Diver Surveys}

\section{Survey Effort}

The distance between frames sampled at 30-sec intervals from benthic tow imagery depends on the tow speed; the average interframe distance ranged from $16.5 \mathrm{~m}$ to $23.6 \mathrm{~m}$ (mean $=20.3 \mathrm{~m}, n=12$ tows). The average benthic area captured in laser-scaled frames from the Northwestern Hawaiian Islands and applied to the Wake tows was $0.583 \mathrm{~m}^{2}$ ( $\mathrm{SE}=0.01 \mathrm{~m}^{2}, n=6398$ frames). Towed divers surveyed $22.5 \mathrm{~km}$ of benthic habitat (Table 1, Figure 2), from which 1038 frames were analyzed. Given the 3:4 aspect ratio of the captured frames and extrapolating to the total number of consecutive, nonoverlapping still frames that compose the benthic imagery, this benthic analysis area (1038 frames $\mathrm{x} 0.583 \mathrm{~m}^{2} /$ frame $=605 \mathrm{~m}^{2}$ ) samples a total survey area of 19,842 $\mathrm{m}^{2}$ (Table 1 ).

Survey effort, assessed by the area analyzed in sampled frames, was greater on the southwest than the northeast fore-reef slope (323 $\mathrm{m}^{2}$ and $283 \mathrm{~m}^{2}$, respectively; Table 1). Of the three depth strata, survey effort was greatest at deep $(18.2-28.5 \mathrm{~m})$ depths. The shallow stratum $(<9.1 \mathrm{~m})$ was only surveyed along the southeasterly portion of the southwest fore reef (Figure 2).

\section{Spatial Analyses of Benthic Cover and Composition}

Percent cover estimates of benthic components from analysis of towed-diver survey imagery exhibited 39\% average similarity among all southwest fore-reef slope samples $(n=553)$ and $42 \%$ average similarity among all northeast fore-reef slope samples $(n=485)$ (Table 1$)$, but average dissimilarity between the two fore-reef sectors was $68 \%$. The northeast sector was dominated by coral (54\% of cover) (Table 1), while the southwest sector was dominated by a combination of macroalgae and turf-covered pavement (29\% and 23\% of cover, respectively). Average similarity within the five strata ranged from $38 \%$ to $48 \%$, with the lowest similarities found among shallow and deep southwest fore-reef samples and 
the highest among moderate-depth northeast fore-reef samples (Table 1). The highest coral cover (57\%) as well as the highest coralline algal cover (8\%) was found in the deep northeast stratum.

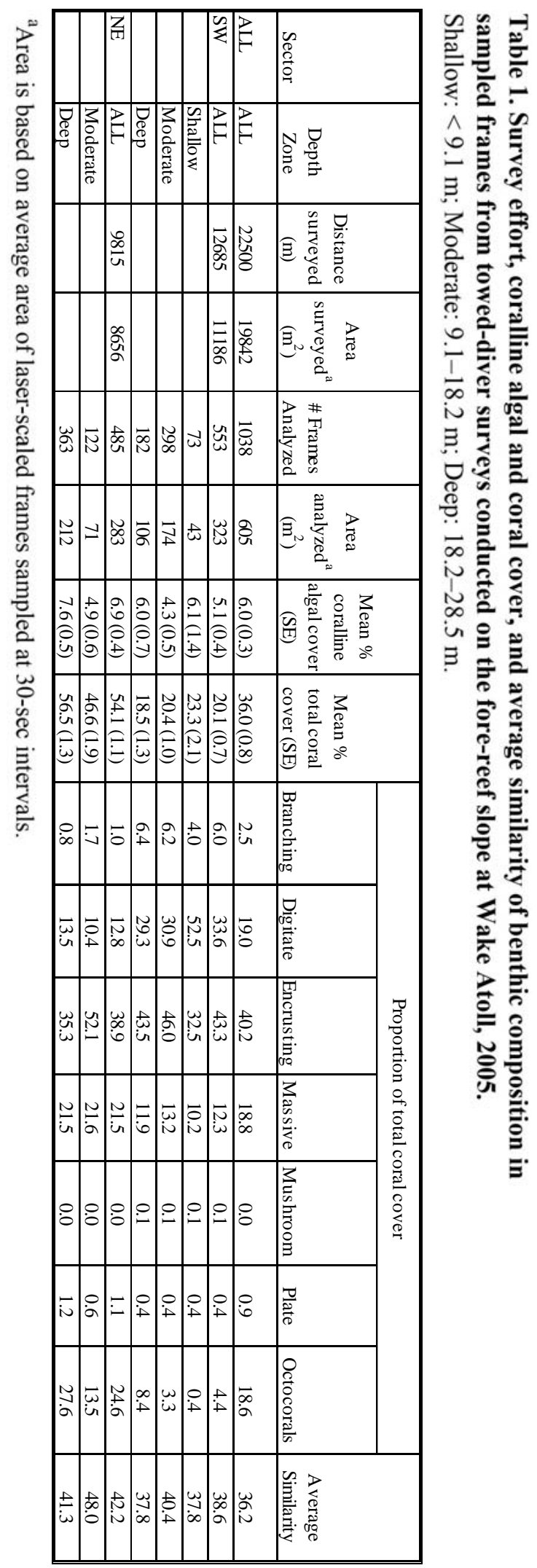


One-way ANOSIM of towed-diver survey data revealed percent cover of benthic components to be significantly different among the five strata (global $R=0.171, p=0.0001$ ). Of the 10 pairwise tests, the greatest differences were found between the deep northeast and each of the shallow and deep southwest fore-reef strata ( $R=0.32$ and 0.30, respectively) (Figure 3). SIMPER tests revealed that a large suite of benthic components contributed to the differences among the strata with turf-covered pavement, macroalgae, and sand making the largest contributions.

\section{Wake 2005 Towed-diver Surveys}

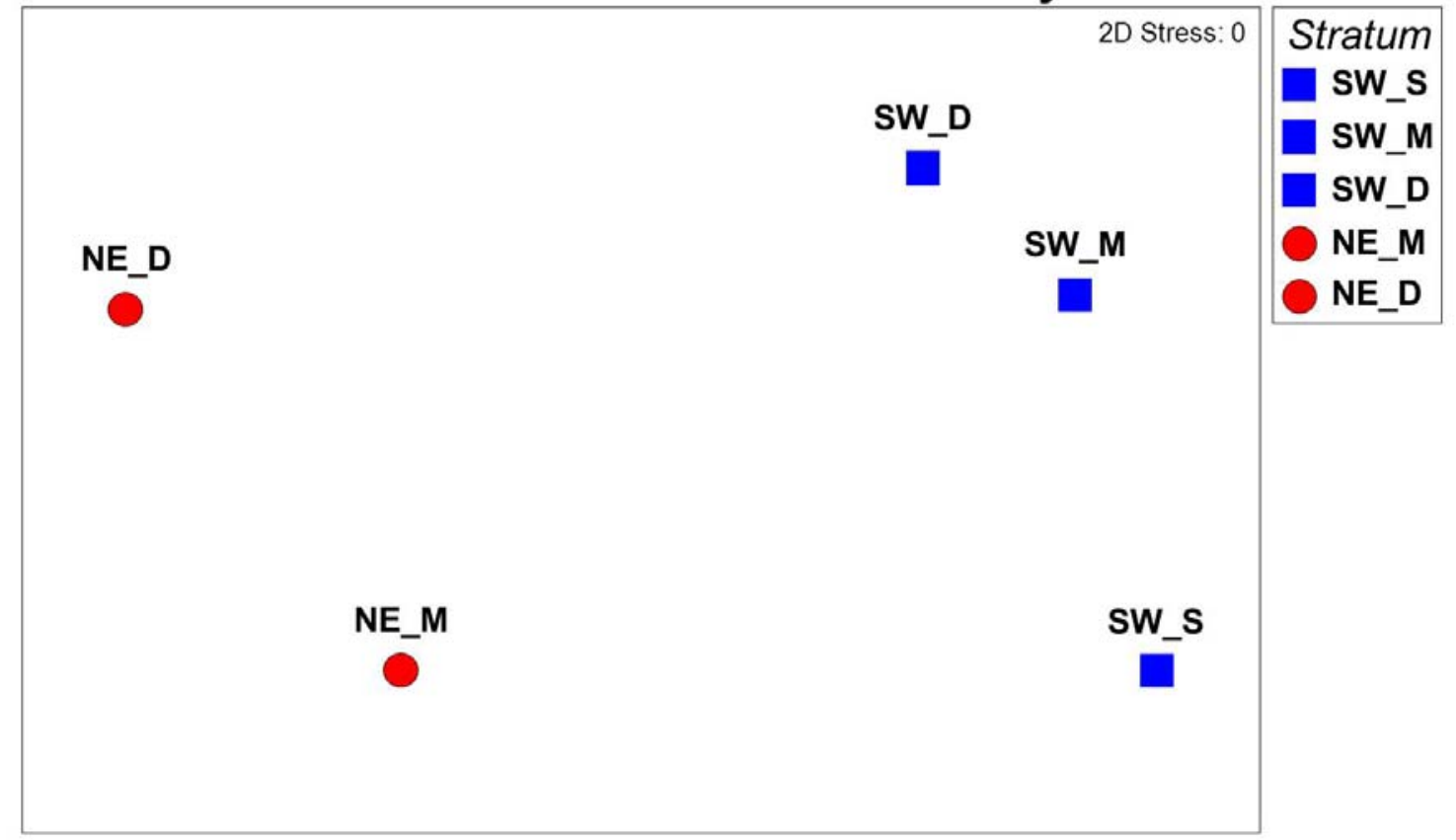

Figure 3. Nonmetric multidimensional scaling (nMDS) ordination depicting relationships of benthic communities based on percent cover data from towed-diver surveys. Each symbol represents the average of data derived from analysis of imagery captured at 30-sec intervals. Stratum key represents

Sector_Depth, where SW = southwest and NE = northeast for sector; $\mathrm{S}=$ shallow, $\mathrm{M}=$ moderate, and $\mathrm{D}$ $=$ deep for depth.

\section{Spatial Analyses of Coral Cover and Composition}

Mean total coral cover on the fore-reef slope was 36.0\% (SE 0.8, $n=1038$ ), with coral cover substantially higher in the northeast sector (mean $54.1 \%$, SE 1.1, $n=485$ ) than the southwest sector (mean 20.1\%, SE 0.7, $n=553$ ) (Table 1). Of the five surveyed strata, mean coral cover was highest (56.5\%) on the deep northeast fore reef and lowest (18.5\%) on the deep southwest fore reef. Average similarity of coral growth form relative abundance derived from analysis of towed-diver survey imagery ranged from $45 \%$ to $54 \%$, with the lowest average similarities found among the deep southwest and deep northeast samples, and the highest among the shallow southwest samples.

Encrusting corals were the most abundant scleractinian growth form in all five fore reef strata except the shallow southwest, where digitate growth forms predominated (Table 1). Digitate corals were the next most abundant scleractinian growth form in the two other southwest strata (Figure 4), while corals with a massive growth form were the second most abundant scleractinian type in the northeast strata. Octocorals accounted for $25 \%$ of total coral cover in the northeast sector but were uncommon in the southwest sector. Branching, solitary mushroom, and plate-like coral growth forms were uncommon to rare in all five surveyed strata. 

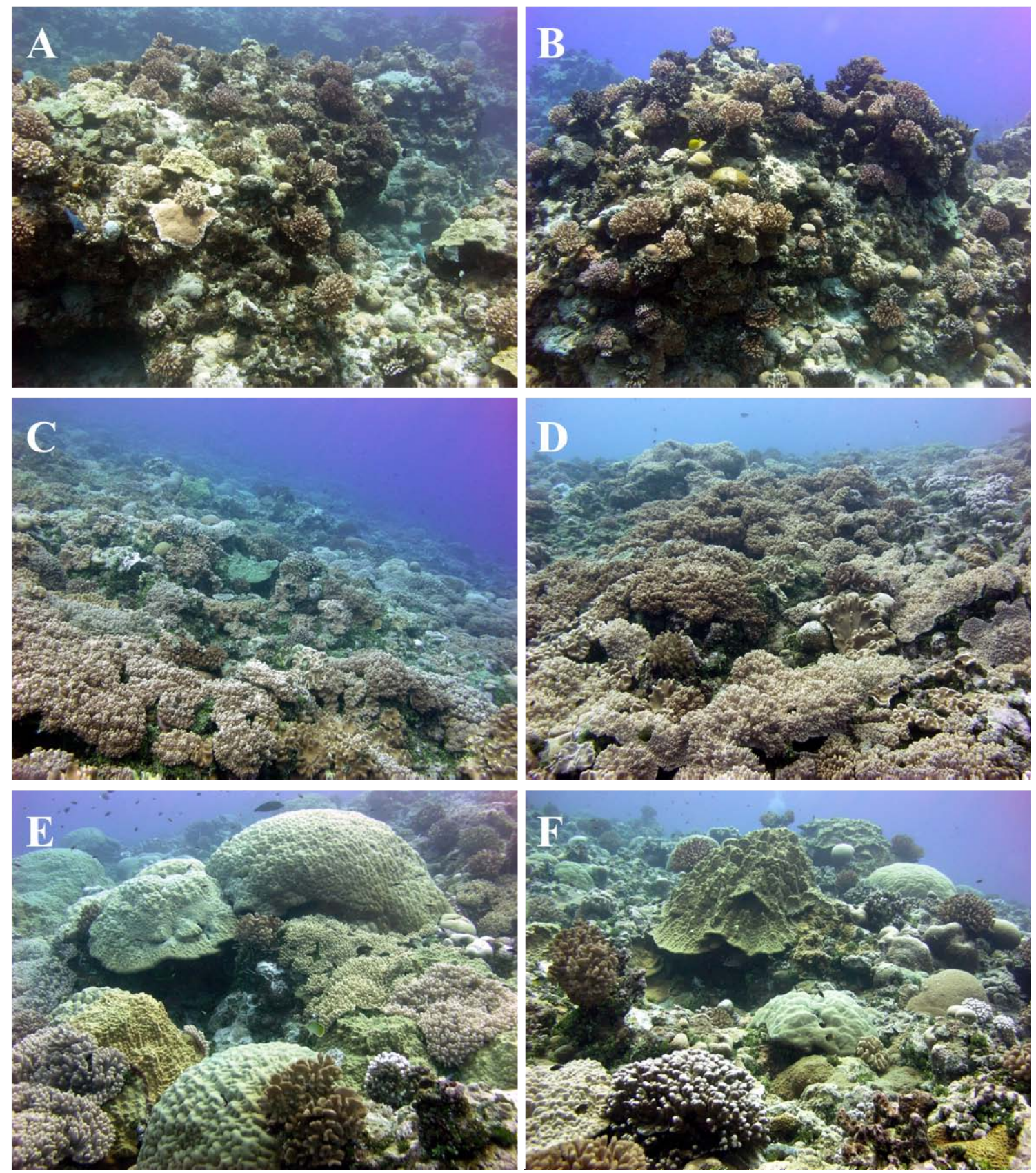

Figure 4. Benthic communities in two fore-reef sectors at Wake Atoll. (a, b) Southwest sector, showing abundance of coral with digitate growth form; (c, d) Northeast sector, showing abundance of octocorals; (e, f) Northeast sector, showing abundance of coral with massive growth form. All photos acquired by the lead author as a roving diver at moderate depths.

\section{Species Inventory of Corals and Other Anthozoans}

A total of 82 species of stony, soft, and hydrozoan corals and 1 other anthozoan were recorded during surveys conducted in 2005 (Table 2). When combined with species lists by Maragos (unpublished, 1979) and Molina (USFWS, 1999), a total of 101 species of stony, soft, and hydrozoan corals and 1 other anthozoan are now reported from Wake Atoll. Within the class Anthozoa, three taxonomic orders are 
represented. Within the stony coral order Scleractinia, 10 families containing 27 genera and 95 species are represented.

Of the 80 scleractinian and hydrozoan taxa whose identity were well established, 66 (82.5\%) have been reported from the Mariana Islands, 58 (72.5\%) from the northern Marshall Islands, and 19 (23.8\%) from the Hawaiian Islands.

\section{Site-Specific Surveys: Photoquadrats}

\section{Spatial Analyses of Benthic Cover and Composition}

All fore-reef surveys were conducted in the moderate depth zone. Percent cover estimates of benthic components from analysis of photoquadrat imagery exhibited 35\% average similarity among all southwest fore-reef samples $(n=84)$ and 33\% average similarity among all northeast fore-reef samples $(n$ $=60$ ), but average dissimilarity between southwest and northeast fore-reef samples was $72 \%$.

Scleractinian and octocoral cover were greatest on the northeast fore reef, while macroalgae and pavement covered with turf algae dominated the southwest fore reef. Sand dominated the single, shallow (2-3 m) site surveyed in the lagoon (Table 3).

One-way ANOSIM revealed percent cover of benthic components to be significantly different between the two fore-reef sectors (global $R=0.186, p=0.0001$ ). SIMPER tests indicated that a large suite of benthic components contributed to the differences between the two fore-reef sectors with turfcovered pavement and sand making the strongest contributions.

\section{Spatial Analyses of Coral Cover and Composition}

Mean total coral cover ranged from $10.2 \%$ at the single site surveyed in the lagoon to $47.2 \%$ on the northeast fore reef (Table 4). Estimates of coral relative abundance derived from analysis of photoquadrat imagery exhibited $27 \%$ average similarity among all southwest fore-reef samples and $20 \%$ average similarity among all northeast fore-reef samples, but average dissimilarity between southwest and northeast fore-reef samples was $80 \%$.

Twelve scleractinian, two alcyonacean (the octocorals Lobophytum and Sinularia), and one hydrozoan coral genera were scored in photoquadrats (Table 4). Cumulative ranked abundance ( $k$ dominance) curves (Figure 5a) demonstrated lower dominance (greater equitability) of coral genera in the northeast relative to the southwest fore reef. ANOSIM revealed a significant difference between the $k$ dominance curves in the two fore-reef sectors (global $R=0.288, p=0.044$ ). SIMPER revealed that Montipora, Pocillopora, and Favia together accounted for $\sim 50 \%$ of the average dissimilarity between the two fore-reef sectors.

Montipora was the most highly ranked coral genus in both fore-reef sectors, and was the only coral genus seen in photoquadrat imagery at the single site surveyed in the lagoon (Table 4). Pocillopora and Porites were the next most abundant coral genera on the southwest fore reef, while Porites and the octocoral Sinularia were the next most abundant on the northeast fore reef. All other genera individually accounted for $<10 \%$ of the total coral cover in both fore-reef sectors.

\section{Site-Specific Surveys: Coral Belt Transects}

\section{Coral Colony Relative Abundance}

A total of 3578 colonies belonging to 19 scleractinian and 3 alcyonacean (the octocorals Sarcophyton, Sinularia, and Lobophytum) genera were recorded in belt-transects (Table 5). Average similarity of samples within the southwest fore-reef sector (77.2) was greater than the average similarity within the northeast fore-reef sector (69.0; Table 5). 
Table 2. Scleractinian corals, octocorals, hydrozoan corals, and other Anthozoa reported at Wake Atoll from 1979 to 2005 surveys. Species denoted "sensu Randall" identified according to characteristics described in Randall and Myers (1983). RL = IUCN Red List of Threatened Species ${ }^{\text {TM }}$

\begin{tabular}{|c|c|c|c|c|c|c|c|c|}
\hline & \multicolumn{3}{|c|}{ Data Source } & \multicolumn{2}{|c|}{ Records } & \multicolumn{3}{|c|}{ Habitats Observed } \\
\hline $\begin{array}{l}\text { SCLERACTINIAN } \\
\text { CORALS }\end{array}$ & $\begin{array}{c}\text { Maragos } \\
1979\end{array}$ & $\begin{array}{c}\text { Molina } \\
1998\end{array}$ & $\begin{array}{l}\text { Kenyon } \\
\text { \& Bonito } \\
2005 \\
\end{array}$ & Sample & Photo & $\begin{array}{l}\text { Fore } \\
\text { reef }\end{array}$ & $\begin{array}{l}\text { Reef } \\
\text { flat }\end{array}$ & Lagoon \\
\hline $\begin{array}{l}\text { Acanthastrea echinata } \\
\text { A. hillae }\end{array}$ & $\mathrm{X}$ & $\mathrm{X}$ & $\begin{array}{l}\mathrm{X} \\
\mathrm{X} \\
\end{array}$ & $\mathrm{x}$ & $\begin{array}{l}\mathrm{X} \\
\mathrm{X} \\
\end{array}$ & $\begin{array}{l}\mathrm{X} \\
\mathrm{X} \\
\end{array}$ & $\mathrm{x}$ & $\mathrm{x}$ \\
\hline $\begin{array}{l}\text { Acropora abrotanoides } \\
\text { A. aculeus }{ }^{\mathrm{RL}} \\
\text { A. acuminata } \mathrm{RL} \\
\text { A. cf. cerealis }\end{array}$ & $\mathrm{X}$ & $\mathrm{X}$ & $\mathrm{X}$ & $\mathrm{x}$ & $\mathrm{x}$ & $\begin{array}{l}\mathrm{X} \\
\mathrm{x}\end{array}$ & $\mathrm{x}$ & $\mathrm{x}$ \\
\hline A. formosa & $\mathrm{X}$ & & & & & & $\mathrm{x}$ & $\mathrm{x}$ \\
\hline A. humilis & & & $X$ & $\mathrm{x}$ & $\mathrm{x}$ & $\mathrm{x}$ & & \\
\hline A. hyacinthus & & & $\mathrm{X}$ & $\mathrm{x}$ & & $\mathrm{x}$ & & \\
\hline A. lutkeni & & & $\mathrm{X}$ & & $\mathrm{x}$ & $\mathrm{x}$ & & \\
\hline A. cf. microclados & & & $\mathrm{X}$ & $\mathrm{x}$ & $\mathrm{x}$ & $\mathrm{x}$ & & \\
\hline A. nasuta & $\mathrm{X}$ & $\mathrm{X}$ & & & & $\mathrm{x}$ & $\mathrm{x}$ & $\mathrm{x}$ \\
\hline A. ocellata sensu Randall & & & $\mathrm{X}$ & & & $\mathrm{x}$ & & \\
\hline A. palmerae ${ }^{\mathrm{RL}}$ & & & $\mathrm{X}$ & & & $\mathrm{x}$ & & \\
\hline A. cf. striata & & & $\mathrm{X}$ & $\mathrm{x}$ & $\mathrm{x}$ & & & $\mathrm{x}$ \\
\hline A. surculosa & & & $\mathrm{X}$ & $\mathrm{x}$ & $\mathrm{x}$ & $\mathrm{X}$ & & \\
\hline A. valida & $\mathrm{X}$ & $\mathrm{X}$ & $\mathrm{X}$ & $\mathrm{x}$ & $\mathrm{x}$ & $\mathrm{x}$ & $\mathrm{x}$ & $\mathrm{x}$ \\
\hline Acropora sp. $\mathrm{A}^{1}$ & & & $\mathrm{X}$ & $\mathrm{x}$ & $\mathrm{x}$ & $\mathrm{x}$ & $\mathrm{x}$ & $\mathrm{x}$ \\
\hline Acropora sp. $\mathrm{B}^{2}$ & & & $\mathrm{X}$ & $\mathrm{x}$ & $\mathrm{x}$ & $\mathrm{x}$ & & \\
\hline Acropora sp. $\mathrm{C}^{3}$ & & & $\mathrm{X}$ & $\mathrm{x}$ & $\mathrm{x}$ & $\mathrm{x}$ & & $\mathrm{x}$ \\
\hline Acropora sp. $\mathrm{D}^{4}$ & & & $\mathrm{X}$ & $\mathrm{x}$ & $\mathrm{x}$ & $\mathrm{x}$ & & \\
\hline $\begin{array}{l}\text { Astreopora myriophthalma } \\
\text { A. randalli }\end{array}$ & & $\mathrm{X}$ & $\begin{array}{l}X \\
X\end{array}$ & $\mathrm{x}$ & $\begin{array}{l}\mathrm{x} \\
\mathrm{x}\end{array}$ & $\begin{array}{l}\mathrm{x} \\
\mathrm{x}\end{array}$ & $\mathrm{x}$ & \\
\hline $\begin{array}{l}\text { Cyphastrea chalcidicum } \\
\text { C. microphthalma }\end{array}$ & & $X$ & $\begin{array}{l}X \\
X\end{array}$ & $\begin{array}{l}x \\
x\end{array}$ & $\begin{array}{l}\mathrm{X} \\
\mathrm{x}\end{array}$ & $\begin{array}{l}\mathrm{X} \\
\mathrm{X}\end{array}$ & $\mathrm{x}$ & $\mathrm{x}$ \\
\hline C. serailia & $X$ & $\mathrm{X}$ & $\mathrm{X}$ & & $\mathrm{x}$ & $\mathrm{x}$ & $\mathrm{x}$ & $\mathrm{x}$ \\
\hline Echinopora lamellosa & & $\mathrm{X}$ & $\mathrm{X}$ & $\mathrm{x}$ & $\mathrm{x}$ & $\mathrm{x}$ & & \\
\hline Favia favus & & $\mathrm{X}$ & $\mathrm{X}$ & & $\mathrm{x}$ & $\mathrm{x}$ & & \\
\hline F. helianthoides & & & $\mathrm{X}$ & $\mathrm{x}$ & $\mathrm{x}$ & $\mathrm{x}$ & & \\
\hline F. matthai & & & $\mathrm{X}$ & $\mathrm{x}$ & $\mathrm{x}$ & $\mathrm{x}$ & $\mathrm{X}$ & $\mathrm{x}$ \\
\hline F. pallida & $\mathrm{X}$ & $\mathrm{X}$ & $\mathrm{X}$ & $\mathrm{x}$ & $\mathrm{x}$ & $\mathrm{x}$ & $\mathrm{x}$ & \\
\hline F. speciosa & $\mathrm{X}$ & & & & & & $\mathrm{x}$ & \\
\hline F. stelligera & $\mathrm{X}$ & $\mathrm{X}$ & $\mathrm{X}$ & $\mathrm{x}$ & $\mathrm{x}$ & $\mathrm{x}$ & $\mathrm{x}$ & \\
\hline Favia sp. & & & $\mathrm{X}$ & & $\mathrm{x}$ & $\mathrm{x}$ & & \\
\hline $\begin{array}{l}\text { Favites abdita } \\
\text { F. complanata }\end{array}$ & $\mathrm{X}$ & $\mathrm{X}$ & X & & & $\begin{array}{l}x \\
x\end{array}$ & $\mathrm{x}$ & $\mathrm{x}$ \\
\hline F. flexuosa & X & $\mathrm{X}$ & & & & $\mathrm{x}$ & $\mathrm{x}$ & \\
\hline F. halicora & $X$ & $\mathrm{X}$ & & $\mathrm{x}$ & & $\mathrm{x}$ & $\mathrm{x}$ & \\
\hline Fungia scutaria & & $\mathrm{X}$ & $\mathrm{X}$ & $\mathrm{x}$ & $\mathrm{x}$ & $\mathrm{x}$ & & \\
\hline Goniastrea edwardsi & & & $\mathrm{X}$ & $\mathrm{x}$ & $\mathrm{x}$ & $\mathrm{x}$ & & $\mathrm{x}$ \\
\hline G. favulus & & $\mathrm{X}$ & $\mathrm{X}$ & $\mathrm{x}$ & $\mathrm{x}$ & $\mathrm{x}$ & & \\
\hline G. pectinata & $\mathrm{X}$ & $X$ & $\mathrm{X}$ & $\mathrm{x}$ & $\mathrm{x}$ & $\mathrm{x}$ & $\mathrm{x}$ & \\
\hline
\end{tabular}




\begin{tabular}{|c|c|c|c|c|c|c|c|c|}
\hline Table 2. Continued & \multicolumn{3}{|c|}{ Data Source } & \multicolumn{2}{|c|}{ Records } & \multicolumn{3}{|c|}{ Habitats Observed } \\
\hline $\begin{array}{l}\text { SCLERACTINIAN } \\
\text { CORALS }\end{array}$ & $\begin{array}{c}\text { Maragos } \\
1979\end{array}$ & $\begin{array}{c}\text { Molina } \\
1998\end{array}$ & $\begin{array}{l}\text { Kenyon } \\
\text { \& Bonito } \\
2005\end{array}$ & Sample & Photo & $\begin{array}{l}\text { Fore } \\
\text { reef }\end{array}$ & $\begin{array}{l}\text { Reef } \\
\text { flat }\end{array}$ & Lagoon \\
\hline G.retiformis & $\mathrm{X}$ & $\mathrm{X}$ & & & & $\mathrm{x}$ & $\mathrm{x}$ & \\
\hline Hydnophora exesa & & & $\mathrm{X}$ & $\mathrm{x}$ & $\mathrm{x}$ & $\mathrm{x}$ & & \\
\hline $\begin{array}{l}\text { Leptastrea aequalis } \\
\text { L. purpurea } \\
\text { L. transversa }\end{array}$ & $\mathrm{X}$ & $X$ & $\begin{array}{l}X \\
X \\
X\end{array}$ & $\begin{array}{l}\mathrm{x} \\
\mathrm{x} \\
\mathrm{x}\end{array}$ & $\begin{array}{l}x \\
x\end{array}$ & $\begin{array}{l}x \\
x\end{array}$ & $\begin{array}{l}\mathrm{X} \\
\mathrm{x}\end{array}$ & \\
\hline Leptoria phrygia & & $\mathrm{X}$ & & & & $\mathrm{x}$ & & \\
\hline Leptoseris mycetoseroides & & $\mathrm{X}$ & $\mathrm{X}$ & $\mathrm{x}$ & $\mathrm{x}$ & $\mathrm{x}$ & & \\
\hline Lobophyllia hemprichi & $\mathrm{X}$ & & & & & $\mathrm{x}$ & & \\
\hline Merulina ampliata & & $\mathrm{X}$ & $\mathrm{X}$ & $\mathrm{x}$ & $\mathrm{x}$ & $\mathrm{x}$ & & \\
\hline $\begin{array}{l}\text { Montastrea curta } \\
\text { M. valenciennesi }\end{array}$ & & $\begin{array}{l}\mathrm{X} \\
\mathrm{X}\end{array}$ & $\begin{array}{l}X \\
X\end{array}$ & $\begin{array}{l}\mathrm{x} \\
\mathrm{x}\end{array}$ & $\begin{array}{l}\mathrm{x} \\
\mathrm{x}\end{array}$ & $\begin{array}{l}\mathrm{x} \\
\mathrm{x}\end{array}$ & $\begin{array}{l}\mathrm{X} \\
\mathrm{X}\end{array}$ & $\mathrm{x}$ \\
\hline $\begin{array}{l}\text { Montipora danae } \\
\text { M. foveolata } \\
\text { M. grisea } \\
\text { M. hoffmeisteri } \\
\text { M. incrassata } \\
\text { M. informis } \\
\text { M. lobulata } \\
\text { M. marshallensis } \\
\text { M. monasteriata } \\
\text { M. tuberculosa } \\
\text { M. verrucosa } \\
\text { Montipora sp. } 2 \text { sensu } \\
\text { Randall } \\
\text { Montipora sp. } \mathrm{A}^{5} \\
\text { Montipora sp. } \mathrm{B}^{6} \\
\text { Montipora sp. } \mathrm{C}^{7} \\
\text { Montipora sp. } \mathrm{D}^{8}\end{array}$ & $\begin{array}{l}X \\
X \\
X \\
X \\
X\end{array}$ & $\begin{array}{l}X \\
X \\
X \\
X\end{array}$ & $\begin{array}{l}X \\
X \\
X \\
X \\
X \\
X \\
\\
X \\
X\end{array}$ & $\begin{array}{l}X \\
X \\
X \\
X \\
X\end{array}$ & $\begin{array}{l}\mathrm{x} \\
\mathrm{X} \\
\mathrm{X} \\
\mathrm{x} \\
\mathrm{x} \\
\mathrm{x}\end{array}$ & $\begin{array}{l}\mathrm{x} \\
\mathrm{x} \\
\mathrm{x} \\
\mathrm{x} \\
\mathrm{x} \\
\mathrm{x} \\
\mathrm{x} \\
\mathrm{x} \\
\mathrm{x} \\
\mathrm{x} \\
\mathrm{x} \\
\mathrm{x} \\
\mathrm{x} \\
\mathrm{x} \\
\mathrm{x}\end{array}$ & $\begin{array}{l}\mathrm{x} \\
\mathrm{x} \\
\mathrm{x} \\
\mathrm{x} \\
\mathrm{x}\end{array}$ & $\begin{array}{l}\mathrm{x} \\
\mathrm{x}\end{array}$ \\
\hline $\begin{array}{l}\text { Pavona duerdeni } \\
\text { P. maldivensis } \\
\text { P. varians } \\
\text { Pavona sp. } 1 \text { sensu Randall }\end{array}$ & & $\mathrm{X}$ & $\begin{array}{l}X \\
X \\
X \\
X\end{array}$ & $\begin{array}{l}\mathrm{x} \\
\mathrm{x} \\
\mathrm{x} \\
\mathrm{x}\end{array}$ & $\begin{array}{l}\mathrm{x} \\
\mathrm{x} \\
\mathrm{x} \\
\mathrm{x}\end{array}$ & $\begin{array}{l}\mathrm{x} \\
\mathrm{x} \\
\mathrm{x} \\
\mathrm{x}\end{array}$ & $\mathrm{x}$ & $\mathrm{x}$ \\
\hline $\begin{array}{l}\text { Platygyra daedalea } \\
\text { P. lamellina } \\
\text { P. sinensis }\end{array}$ & & $\begin{array}{l}\mathrm{X} \\
\mathrm{X}\end{array}$ & $\begin{array}{l}X \\
X\end{array}$ & $\begin{array}{l}\mathrm{X} \\
\mathrm{X}\end{array}$ & $\begin{array}{l}\mathrm{x} \\
\mathrm{x}\end{array}$ & $\begin{array}{l}\mathrm{X} \\
\mathrm{x} \\
\mathrm{x}\end{array}$ & $\mathrm{x}$ & \\
\hline $\begin{array}{l}\text { Pocillopora damicornis } \\
\text { P. elegans }{ }^{\mathrm{RL}} \\
\text { P. eydouxi } \\
\text { P. meandrina } \\
\text { P. setchelli } \\
\text { P. verrucosa }\end{array}$ & $\begin{array}{l}X \\
X \\
X \\
X\end{array}$ & $\begin{array}{l}X \\
X \\
X\end{array}$ & $\begin{array}{l}X \\
X \\
X \\
X \\
X \\
X\end{array}$ & $\mathrm{x}$ & $\begin{array}{l}\mathrm{X} \\
\mathrm{X} \\
\mathrm{X} \\
\mathrm{X} \\
\mathrm{X}\end{array}$ & $\begin{array}{l}\mathrm{x} \\
\mathrm{x} \\
\mathrm{x} \\
\mathrm{x} \\
\mathrm{x}\end{array}$ & $\begin{array}{l}\mathrm{x} \\
\mathrm{x}\end{array}$ & $\mathrm{x}$ \\
\hline $\begin{array}{l}\text { Porites lichen } \\
\text { P. lobata } \\
\text { P. lutea } \\
\text { P. rus } \\
\text { P. solida }\end{array}$ & $\begin{array}{l}X \\
X \\
X\end{array}$ & $\begin{array}{l}X \\
X\end{array}$ & $\begin{array}{l}X \\
X \\
X \\
X \\
X\end{array}$ & $\begin{array}{l}\mathrm{X} \\
\mathrm{X} \\
\mathrm{X} \\
\mathrm{X}\end{array}$ & $\begin{array}{l}\mathrm{X} \\
\mathrm{X} \\
\mathrm{X} \\
\mathrm{X} \\
\mathrm{X}\end{array}$ & $\begin{array}{l}\mathrm{x} \\
\mathrm{x} \\
\mathrm{x} \\
\mathrm{x} \\
\mathrm{x}\end{array}$ & $\begin{array}{l}\mathrm{x} \\
\mathrm{x}\end{array}$ & $\begin{array}{l}\mathrm{x} \\
\mathrm{x}\end{array}$ \\
\hline
\end{tabular}




\begin{tabular}{|c|c|c|c|c|c|c|c|c|}
\hline Table 2. Continued & \multicolumn{3}{|c|}{ Data Source } & \multicolumn{2}{|c|}{ Records } & \multicolumn{3}{|c|}{ Habitats Observed } \\
\hline $\begin{array}{l}\text { SCLERACTINIAN } \\
\text { CORALS }\end{array}$ & $\begin{array}{c}\text { Maragos } \\
1979\end{array}$ & $\begin{array}{c}\text { Molina } \\
1998\end{array}$ & $\begin{array}{l}\text { Kenyon } \\
\text { \& Bonito } \\
2005 \\
\end{array}$ & Sample & Photo & $\begin{array}{l}\text { Fore } \\
\text { reef }\end{array}$ & $\begin{array}{l}\text { Reef } \\
\text { flat }\end{array}$ & Lagoon \\
\hline $\begin{array}{l}\text { Psammocora profundacella } \\
\text { Psammocora sp. }\end{array}$ & $\mathrm{X}$ & & $\begin{array}{l}\mathrm{X} \\
\mathrm{X} \\
\end{array}$ & $\begin{array}{l}\mathrm{x} \\
\mathrm{X}\end{array}$ & $\begin{array}{l}\mathrm{x} \\
\mathrm{X}\end{array}$ & $\begin{array}{l}\mathrm{x} \\
\mathrm{x}\end{array}$ & $\mathrm{x}$ & \\
\hline Scapophyllia cylindrica & & & $\mathrm{X}$ & $\mathrm{x}$ & $\mathrm{x}$ & $\mathrm{x}$ & & \\
\hline Seriatopora hystrix & $\mathrm{X}$ & & & & & & $\mathrm{x}$ & \\
\hline Stylophora mordax & & & $\mathrm{X}$ & $\mathrm{x}$ & $\mathrm{x}$ & $\mathrm{x}$ & & \\
\hline $\begin{array}{l}\text { Symphyllia radians } \\
\text { S. recta }\end{array}$ & & $\begin{array}{l}X \\
X\end{array}$ & $\mathrm{X}$ & $\mathrm{x}$ & $\mathrm{x}$ & $\begin{array}{l}\mathrm{X} \\
\mathrm{x}\end{array}$ & & \\
\hline Tubastrea sp. & & & $\mathrm{X}$ & $\mathrm{x}$ & $\mathrm{x}$ & $\mathrm{x}$ & & \\
\hline $\begin{array}{l}\text { OCTOCORALLIA CORALS } \\
\text { Lobophytum sp. }\end{array}$ & & & $\mathrm{X}$ & $\mathrm{x}$ & $\mathrm{x}$ & $\mathrm{x}$ & & \\
\hline Sarcophyton sp. & & & $\mathrm{X}$ & $\mathrm{x}$ & $\mathrm{x}$ & $\mathrm{x}$ & $\mathrm{x}$ & \\
\hline Sinularia sp. & & & $\mathrm{X}$ & $\mathrm{x}$ & $\mathrm{x}$ & $\mathrm{x}$ & & \\
\hline Stereonephthya sp. & & & $\mathrm{X}$ & $\mathrm{x}$ & $\mathrm{x}$ & $\bar{x}$ & & \\
\hline $\begin{array}{l}\text { HYDROZOAN CORALS } \\
\text { Millepora exaesa } \\
\text { M. platyphylla } \\
\end{array}$ & $\mathrm{X}$ & $X$ & $\mathrm{X}$ & $\mathrm{x}$ & $\mathrm{x}$ & $\begin{array}{l}\mathrm{X} \\
\mathrm{X}\end{array}$ & & \\
\hline $\begin{array}{l}\text { ZOANTHIDS } \\
\text { Palythoa sp. }\end{array}$ & & & $\mathrm{X}$ & $\mathrm{X}$ & $\mathrm{X}$ & $\mathrm{x}$ & & \\
\hline $\begin{array}{l}{ }^{1} \text { caespitose colonies; tubular in } \\
\text { corallites; }{ }^{3} \text { corymbose colonies } \\
\text { corallites ; }{ }^{5} \text { encrusting colonies } \\
{ }^{7} \text { encrusting colonies with coen } \\
\text { coenosteal papillae mostly forr }\end{array}$ & pient axia & $\begin{array}{l}\text { corallite } \\
\text { m radial } \\
\text { teal pap } \\
\text { e, often }\end{array}$ & $\begin{array}{l}\text { are comm } \\
\text { corallites; } \\
\text { llae; }{ }^{6} \text { encru } \\
\text { orming shy }\end{array}$ & $\begin{array}{l}\text { a }{ }^{2} \text { thick- } \\
\text { aespitose } \\
\text { ing colon } \\
\text { tridges; }\end{array}$ & $\begin{array}{l}\text { ranche } \\
\text { colonie } \\
\text { ies with } \\
\text { encrusti }\end{array}$ & $\begin{array}{l}\text { with } \\
\text { vith } \\
\text { omi } \\
\text { col }\end{array}$ & $\begin{array}{l}\text { iform } \\
\text { llar rac } \\
\text { t theca } \\
\text { s with }\end{array}$ & $\begin{array}{l}\text { dial } \\
\text { al } \\
\text { papillae; }\end{array}$ \\
\hline
\end{tabular}

Table 3. Mean percent cover of benthic components, derived from photoquadrat imagery at Wake Atoll, 2005.

\begin{tabular}{|l|c|c|c|}
\hline \multicolumn{1}{|c|}{ Category } & Southwest Fore reef & Northeast Fore reef & Lagoon Patch \\
\hline Scleractinian corals & 16.6 & 39.4 & 10.2 \\
\hline Octocorals & 0.1 & 7.8 & 0.0 \\
\hline Millepora & 0.2 & 0.0 & 0.0 \\
\hline Halimeda & 10.9 & 10.1 & 0.0 \\
\hline Other Macroalgae & 14.7 & 9.7 & 11.3 \\
\hline Coralline Algae & 0.4 & 5.5 & 0.0 \\
\hline Other Invertebrates & 0.2 & 0.0 & 0.7 \\
\hline Pavement & 26.6 & 25.3 & 12.0 \\
\hline Sand & 22.0 & 2.0 & 59.8 \\
\hline Rubble & 8.3 & 0.2 & 6.0 \\
\hline \multicolumn{4}{|l|}{} \\
\hline Average Similarity & 34.6 & 32.7 & 44.0 \\
\hline
\end{tabular}


Table 4. Relative abundance of coral genera, expressed as percent of mean total coral cover, derived from photoquadrat imagery at Wake Atoll, 2005.

\begin{tabular}{|c|c|c|c|}
\hline Genus & Southwest Fore reef & Northeast Fore reef & Lagoon Patch \\
\hline Acanthastrea & 4.7 & 6.4 & 0.0 \\
\hline Astreopora & 0.3 & 9.1 & 0.0 \\
\hline Cyphastrea & 1.9 & 7.5 & 0.0 \\
\hline Favia & 6.2 & 5.9 & 0.0 \\
\hline Favites & 0.0 & 0.2 & 0.0 \\
\hline Goniastrea & 2.4 & 2.3 & 0.0 \\
\hline Leptastrea & 0.1 & 0.2 & 0.0 \\
\hline Lobophytum & 0.0 & 5.5 & 0.0 \\
\hline Millepora & 1.2 & 0.0 & 0.0 \\
\hline Montastrea & 2.8 & 3.5 & 0.0 \\
\hline Montipora & 39.1 & 27.6 & 100.0 \\
\hline Pavona & 0.6 & 0.2 & 0.0 \\
\hline Pocillopora & 27.4 & 3.3 & 0.0 \\
\hline Porites & 12.8 & 17.2 & 0.0 \\
\hline Sinularia & 0.6 & 11.2 & 0.0 \\
\hline Mean (SE) coral cover, \% & $16.9(2.0)$ & $47.2(3.7)$ & $10.2(5.0)$ \\
\hline Average Similarity & 27.1 & 20.1 & 100.0 \\
\hline
\end{tabular}

Cumulative ranked abundance ( $k$-dominance) curves (Figure $5 b$ ) demonstrated lower dominance (greater equitability) of coral genera in the northeast relative to the southwest fore reef. Four scleractinian genera-Pocillopora, Montipora, Favia, and Goniastrea-accounted for $>70 \%$ of all colonies enumerated in the southwest sector, while the four most abundant coral genera in the northeast sector (Montipora, Favia, Pocillopora, and Acanthastrea) accounted for only slightly more than half of all colonies enumerated in that sector (Table 5, Figure 5b). ANOSIM revealed a significant difference between the $k$-dominance curves in the two fore-reef sectors (global $R=0.814, p=0.001$ ). SIMPER revealed that Pocillopora and Lobophytum accounted for the greatest contributions to the dissimilarities between the two fore-reef sectors. All other genera individually accounted for $<10 \%$ of the total number of colonies in both fore-reef sectors.

At the single site surveyed in the lagoon, Montipora accounted for close to $80 \%$ of enumerated colonies.

\section{Coral Size-class Distributions}

All Pocillopora colonies had a maximum diameter $<40 \mathrm{~cm}$ (Figure 6a, b). Size-class distributions of Pocillopora did not vary significantly between the two fore-reef sectors (global $R=0.184, p=0.072$ ), with $>75 \%$ of the colonies in each sector having a maximum diameter between 10 and $40 \mathrm{~cm}$. Size-class distributions of Montipora did not vary significantly between the two fore-reef sectors (global $R=0.123, p=0.120$ ), with $>15 \%$ of the colonies in each sector having a maximum diameter $>40 \mathrm{~cm}$ (Figure 6c, d). 

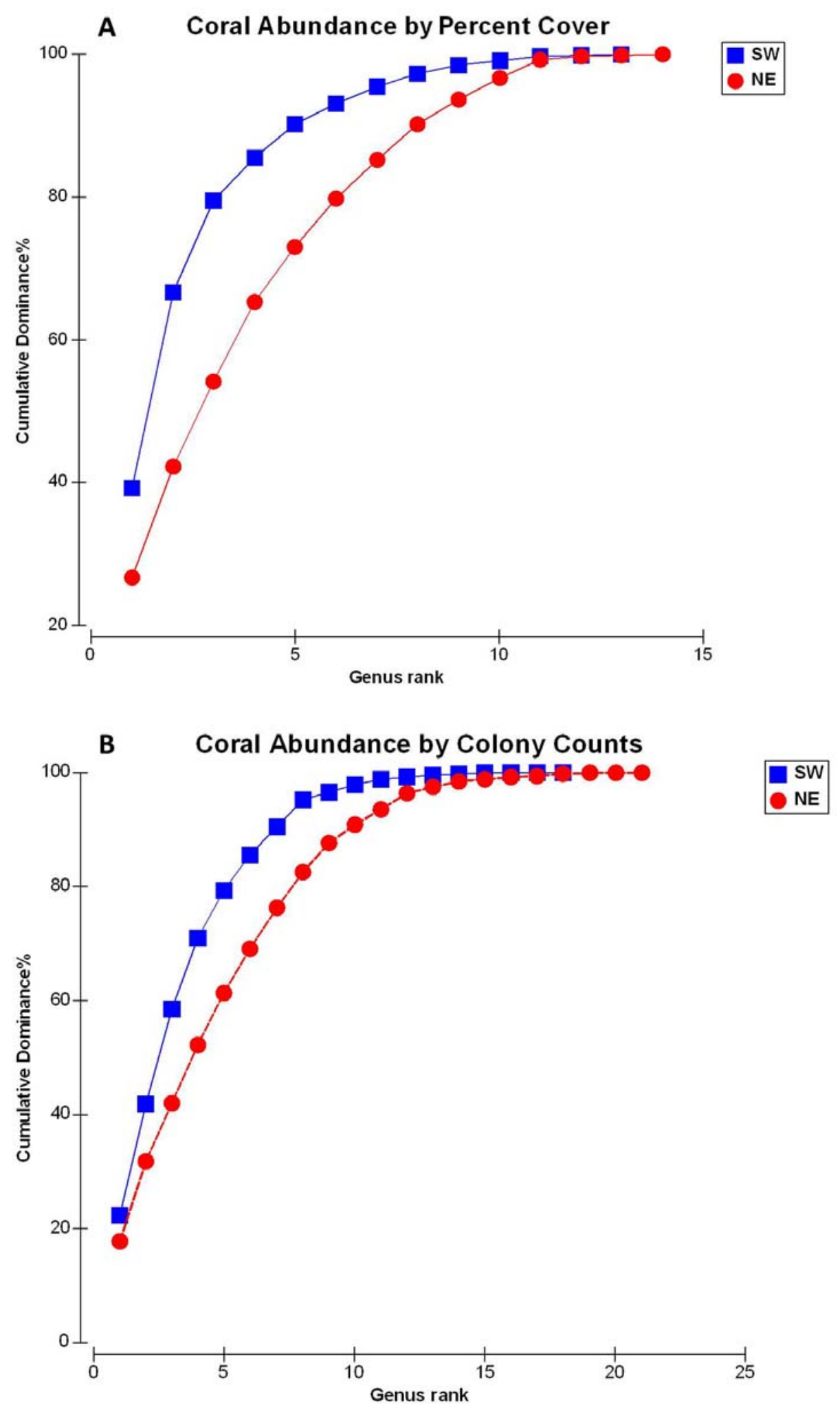

Figure 5. Cumulative ranked abundance curves ( $k$-dominance curves) for corals in two fore-reef sectors at Wake Atoll. (a) Based on percent cover data from photoquadrats. (b) Based on colony counts in belt transects. SW = southwest, $\mathrm{NE}=$ northeast 
Table 5. Relative abundance of coral genera, expressed as percent of total number of coral colonies, derived from belt-transect surveys at Wake Atoll, 2005.

\begin{tabular}{|l|c|c|c|}
\hline \multicolumn{1}{|c|}{ Genus } & Southwest Fore reef & Northeast Fore reef & Lagoon Patch \\
\hline Acanthastrea & 8.3 & 10.2 & 1.5 \\
\hline Acropora & 0.1 & 0.3 & 3.0 \\
\hline Astreopora & 1.3 & 3.2 & 0.0 \\
\hline Cyphastrea & 4.9 & 2.8 & 6.1 \\
\hline Echinopora & 0.4 & 0.5 & 0.0 \\
\hline Favia & 16.7 & 13.9 & 4.5 \\
\hline Favites & 0.0 & 0.1 & 0.0 \\
\hline Fungia & 0.0 & 0.4 & 0.0 \\
\hline Goniastrea & 12.4 & 7.2 & 0.0 \\
\hline Leptastrea & 0.4 & 0.1 & 0.0 \\
\hline Lobophytum & 0.0 & 9.0 & 0.0 \\
\hline Montastrea & 4.8 & 6.2 & 4.5 \\
\hline Montipora & 19.6 & 17.8 & 78.8 \\
\hline Pavona & 1.2 & 0.8 & 0.0 \\
\hline Platygyra & 0.1 & 1.1 & 0.0 \\
\hline Pocillopora & 22.2 & 10.4 & 0.0 \\
\hline Porites & 6.2 & 5.1 & 1.5 \\
\hline Psammocora & 0.0 & 0.0 & 0.0 \\
\hline Sarcophtyton & 0.0 & 2.8 & 0.0 \\
\hline Scapophyllia & 0.0 & 0.1 & 0.0 \\
\hline Sinularia & 1.0 & 7.9 & \\
\hline Stylophora & 0.0 & 0.0 & \\
\hline & & & 0.0 \\
\hline Total colonies enumerated & 2084 & & \\
\hline Average Similarity & & & \\
\hline & & & \\
\hline
\end{tabular}




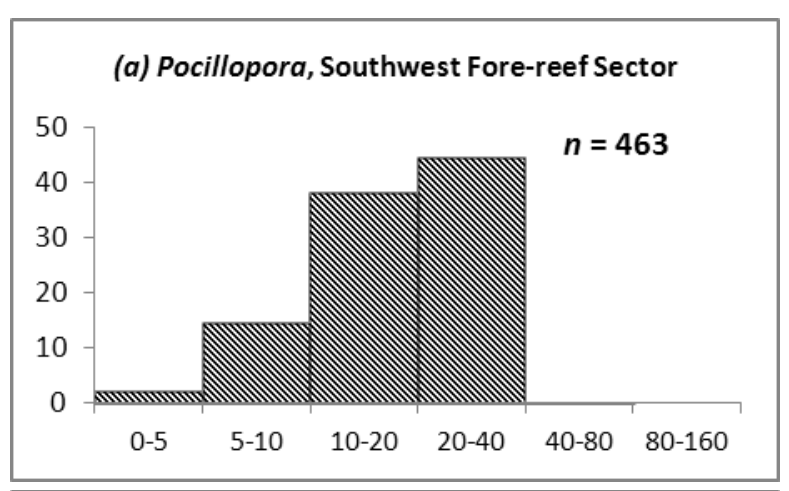

(c) Montipora, Southwest Fore-reef Sector

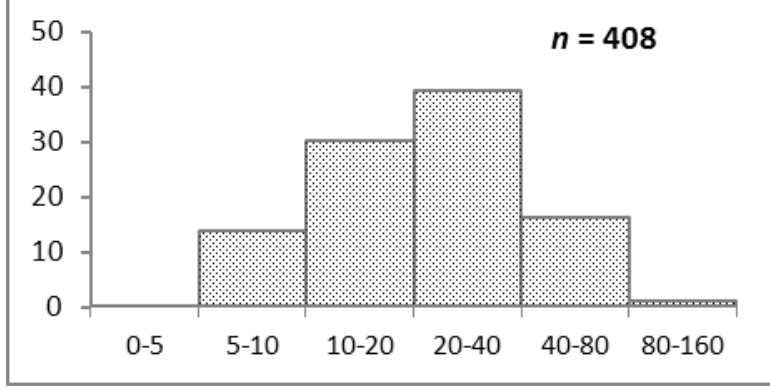

(b) Pocillopora, Northeast Fore-reef Sector

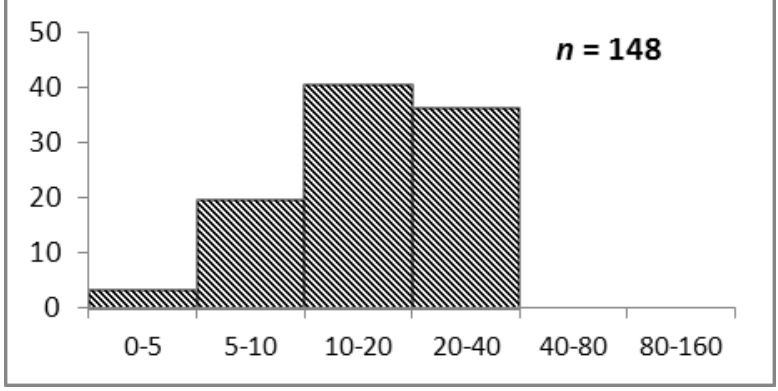

(d) Montipora, Northeast Fore-reef Sector

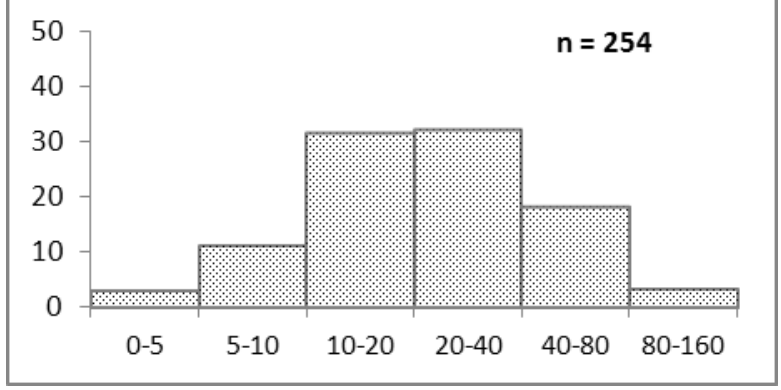

Figure 6. Size -class (cm) distributions of Pocillopora and Montipora in two fore-reef sectors at Wake Atoll. The $\mathrm{x}$-axis is maximum diameter (cm); the y-axis is percent of Pocillopora (a-b) or Montipora (cd) colonies enumerated in each sector.

\section{DISCUSSION}

Little published or unpublished information exists concerning the coral fauna at Wake Atoll. Here, we apply multivariate statistical analyses to data acquired in 2005 from several complementary survey methods that operate at different scales of spatial and taxonomic resolution to characterize the benthic fore-reef communities at Wake Atoll in relationship to strata defined by geographic sector and depth zone. Analysis of imagery recorded during broad-scale surveys conducted by towed divers provides a spatially extensive assessment of benthic communities at a relatively coarse level of taxonomic resolution, while site-specific surveys using photoquadrats and belt transects enable finer resolution of corals to the genus or species level. In the following discussion, the diverse metrics generated by these three methodologies are synthesized to provide a baseline description of fore-reef coral communities at Wake Atoll.

Towed-diver surveys revealed broad differences between sectors and strata in overall benthic composition, mean coral and coralline algal cover, and dominant coral growth forms. While within-sector similarity of overall benthic composition was comparable for both the SW and NE sectors (39\% and 42\%, respectively), dissimilarity of benthic composition between the two sectors was high (68\%) (Figure 3). Among the depth strata within the sectors, the greatest difference in overall benthic composition was found between the deep NE and two of the SW strata. In examining the coral component of overall benthic composition, mean coral cover in the NE sector was more than 2.5 times greater than in the SW sector (54.1\% and $20.1 \%$, respectively), with octocorals accounting for $>25 \%$ of the total coral cover in the NE sector but $<5 \%$ in the SW sector. Encrusting and massive coral growth forms dominated in the NE sector, while encrusting and digitate coral growth forms dominated in the SW sector. Of the depth strata within the sectors, the greatest difference in coral growth form composition was found between the deep NE and the shallow SW strata, congruent with the major strata differences in overall benthic 
composition. Moreover, the deep NE stratum showed among the highest diversity of growth forms (i.e., lowest within-stratum similarity, 45\%) while the shallow SW stratum showed the lowest diversity of growth forms (i.e., highest within-stratum similarity, 54\%). The deep NE stratum was also distinguished by the highest total coral cover (56.5\%), octocoral cover ( $27.6 \%$ of total coral cover), and coralline algal cover (8\%).

Complementing the results from towed-diver surveys with regard to overall benthic composition, sitespecific photoquadrats revealed comparable within-sector similarity for both the SW and NE sectors (35\% and 33\%, respectively), but high dissimilarity (72\%) between the two sectors. Consistent with results from broad-scale towed-diver surveys, mean total coral cover derived from photoquadrats in the NE sector was more than 2.5 times greater than in the SW sector (47.2\% and $16.9 \%$, respectively), with good agreement in the magnitude of the independent estimates derived from towed-diver surveys and from photoquadrats. Octocorals accounted for $16.5 \%$ of the total coral cover in the NE sector but only $3.5 \%$ in the SW sectors; the discrepancy between octocoral relative abundance estimates from toweddiver surveys and photoquadrats in the NE sector (> 25\% vs. 16.5\%) likely reflects the small area sampled by the photoquadrats $\left(8.4 \mathrm{~m}^{2}\right)$ relative to the extensive area sampled by towed-divers $\left(283 \mathrm{~m}^{2}\right.$, Table 1).

Photoquadrat data revealed more taxonomically-detailed patterns characterizing the two fore-reef sectors at moderate depths. Congruent with variability between the NE and SW sector in the relative proportion of different coral growth forms (Table 1), there was high average dissimilarity (80\%) between $\mathrm{NE}$ and SW sectors in the genus-level taxonomic composition of the coral cover. Equitability of the taxonomic composition of coral cover was significantly greater in the NE than the SW sector, though Montipora accounted for the highest contribution to mean total coral cover in both sectors. Porites was among the primary components of coral cover in both sectors, with octocorals and Pocillopora also dominating coral cover in the NE and SW sector, respectively.

In examining coral taxonomic composition using the number of colonies as a metric rather than percent cover, site-specific coral belt-transect data also revealed that equitability of the coral fauna was significantly greater in the NE than the SW sector, though three genera had the greatest relative abundances in both sectors: Montipora, Pocillopora, and Favia. Size class distributions of the most numerically abundant genera, Montipora and Pocillopora, were not significantly different between the two sectors, however.

Wake Atoll supports at least 102 species and 33 genera of corals and other cnidarians based on spatially limited surveys conducted between 1979 and 2005. These consist of 95 species in 27 genera of scleractinian stony corals; 2 species in a single genus of hydrozoan corals; 4 genera of soft octocorals; and 1 genus of zoanthid soft corals (Table 2). Scleractinian species richness at Wake is lower than in the northern Marshall Islands (168 species; Maragos, 1994) and Mariana Islands (377 species; Randall, 2003), but exceeds that in the Hawaiian Islands (65 species; Fenner, 2005). Zoogeographic analysis of the fish fauna (321 species) at Wake by Lobel and Lobel (2004) indicated the greatest species overlap occurred with the northern Mariana islands (87\%) and the Marshall Islands (82\%), and lower species overlap occurred with the southern Mariana Islands (66\%) and Hawaiian Islands (40\%). Zoogeographic analysis of the list of 80 coral species with well-established names presently reported from Wake Atoll also indicates greatest overlap with the Mariana (82.5\%) and the northern Marshall Islands (72.5\%) and lesser overlap with the Hawaiian Archipelago (23.8\%). In comparison, marine benthic algae documented from Wake Atoll also contain components from the Marshall Islands and Hawaiian Islands, but show a closer resemblance to the Hawaiian Islands; of the 107 species of red, brown, and green algae recorded from Wake, 93.4\% are represented in the Hawaiian marine flora whereas only 50.4\% are reported from the Marshall Islands (Tsuda et al., 2010). The coral fauna at both Wake and the northern Marshall Islands remain poorly studied, however, relative to the Mariana Islands and the Hawaiian Islands. More spatiallyextensive surveys and clarification of species that are currently only identified to the genus level are likely to modify the estimates of geographical overlap in this initial analysis. At Wake, greater search effort on the deeper fore reef, reef flat, and lagoon patch reefs will likely yield additional species. 
Five coral species found at Wake are listed on the IUCN Red List of Threatened Species ${ }^{\mathrm{TM}}$ (Acropora aculeus, A. acuminata, A. palmerae, Montipora lobulata, and Pocillopora elegans; Table 2). All five species are categorized as Vulnerable, the lowest level of extinction risk in the Red List 3-tiered system of threatened species, based on the IUCN sub-criterion A4: an observed, estimated, inferred, projected or suspected population size reduction $\geq 30 \%$ over two generations in the past and one into the future, where the generation length was considered as 10 years except for Pocillopora elegans (5 years) (IUCN, 2001; Carpenter et al., 2008). While widely viewed as a useful index in estimating extinction risk, the IUCN Red List of Threatened Species ${ }^{\mathrm{TM}}$ carries no weight of law. In October 2009 the nongovernmental organization Center for Biological Diversity petitioned the NOAA to list 83 species of corals under the U.S. Endangered Species Act (ESA), including the five Wake species reported in this study. The ESA does have the weight of law. The National Marine Fisheries Service is currently leading the process to independently evaluate the extinction risk of these species, and if listed under the ESA, these corals would receive legal protection.

In conducting coral disease assessments at 40 different coral islands, banks, and atolls in the U.S. Pacific, Vargas-Ángel (2009) reported a mean prevalence of coral disease (proportion of colonies manifesting a disease state) of 3.9 at Wake. Though considered a low prevalence of disease, Wake ranked the ninth highest among the 40 locations. Skeletal growth anomalies were the most common affliction (mean prevalence 3.2), followed by tissue loss syndrome (0.3), bleaching (0.2), and pigmentation response (0.1). Although the absence of baseline information prior to the present study makes it impossible to know the degree to which Wake coral communities have been impacted by modern factors affecting reef dynamics (e.g., mass bleaching, crown-of-thorns seastar infestations, coastal point source pollution, sedimentation from dredging and construction, and marine invasive species), the fore-reef coral community appears overall in relatively good condition. Significant restrictions on fishing activities, including a ban on commercial fishing, the use of traps, most nets, automated spear guns, and a prohibition on the take of sharks, rays, bumphead parrotfishes (Bolbometopon muricatum) and napoleon wrasse (Cheilinus undulatus), reduce the threats from overfishing that have been identified as a medium or high threat to over 35\% of the world's coral reefs (Waddell, 2005). Dominance of the reef fish community at Wake by secondary consumers (omnivores and benthic invertivores) (Williams et al., 2010) likely enhances coral health by maintaining grazers that help regulate algal and other epibenthic populations.

Corals and coral reefs are increasingly susceptible to the consequences of global climate change including increased mass coral bleaching and reduced accretion due to ocean acidification (HoeghGuldberg and Bruno, 2010). As the number of reports of degrading coral reefs increases in response to local and global stressors (e.g., Knowlton, 2001; Hughes et al., 2003; Pandolfi, 2005; Hoegh-Guldberg et al., 2007), it becomes increasingly urgent to establish detailed descriptive baselines by which the direction and pace of future changes can be determined. Our application of multivariate statistical analyses to survey data collected at different scales of spatial and taxonomic resolution has discerned spatial variation that provides a baseline for future surveys to detect future trajectories of change.

\section{ACKNOWLEDGMENTS}

This work is part of an interdisciplinary effort by the NOAA Pacific Islands Fisheries Science Center Coral Reef Ecosystem Division to assess and monitor coral-reef ecosystems in the U.S. Pacific in collaboration with marine scientists at the U.S. Fish and Wildlife Service. We thank the officers and crew of the NOAA Ship Oscar Elton Sette for logistic support and field assistance. Molly Timmers and Jacob Asher assisted in the collection of towed-diver survey data; Kimberly Page and Aline Tribollet collected photoquadrat data. Permission to work at Wake Atoll was granted by the U.S. Air Force, Department of Defense. Funding from NOAA's Coral Reef Conservation Program and from the U.S. Fish and Wildlife Service supported this work. 


\section{REFERENCES}

Brainard, R., J. Asher, J. Gove, J. Helyer, J. Kenyon, F. Mancini, J. Miller, S. Myhre, M. Nadon, J. Rooney, R. Schroeder, E. Smith, B. Vargas-Angel, S. Vogt, and P. Vroom. 2008. Coral reef ecosystem monitoring report for American Samoa: 2000-2006. Pacific Islands Fisheries Science Center Special Publication, SP-08 002. Honolulu: Pacific Islands Fisheries Science Center.

Bryan, E.H. 1959. Notes on the geography and natural history of Wake Island. Atoll Research Bulletin 66:1-23.

Carpenter K., M. Abrar, G. Aeby, R.B. Aronson, S. Banks, A. Bruckner, A. Chiriboga, J. Cortés, J.C. Delbeek, L. DeVantier, G.J. Edgar, A.J. Edwards, D. Fenner, H.M. Guzmán, B.W. Hoeksema, G. Hodgson, O. Johan, W.Y. Lichuanan, S.R. Livingstone, E.R. Lovell, J.A. Moore, D.O. Obura, D. Ochavillo, B.A. Polidoro, W.F. Precht, M.C. Quibilan, C. Reboton, Z.T. Richards, A. D. Rogers, J. Sanciangco, A. Sheppard, C. Cheppard, J. Smith, S. Stuart, E. Turak, J.E.N. Veron, C. Wallace, E. Weil, and E. Wood. 2008. One-third of reef-building corals face elevated extinction risk from climate change and local impacts. Science 321:560-564.

Clarke, K.R., and R.N. Gorley. 2006. PRIMER v6: User Manual/Tutorial. Plymouth, England: PRIMERE.

Clarke, K.R., and R.M. Warwick. 2001. Change in marine communities: An approach to statistical analysis and interpretation, 2nd ed. Plymouth, England: PRIMER-E.

Edmondson, C.H., W.K. Fisher, H.L. Clark, A.L. Treadwell, and J.A. Cushman. 1925. Marine zoology of tropical Central Pacific. Bernice P. Bishop Museum Bulletin 27.

Fenner, D. 2005. Corals of Hawai i. Honolulu: Mutual Publishing.

Gregory, H.E. 1924. Report of the director for 1923. Bernice P. Bishop Museum Bulletin 10.

Hoegh-Guldberg, O., and J.F. Bruno. 2010. The impact of climate change on the world's marine ecosystems. Science 328:1523-1528.

Hoegh-Guldberg, O., P.J. Mumby, A.J. Hooten, R.S. Steneck, P. Greenfield, E. Gomez, C.D. Harvell, P.F. Sale, A.J. Edwards, K. Caldeira, N. Knowlton, C.M. Eakin, R. Iglesias-Prieto, N. Muthiga, R.H. Bradbury, A. Dubi, and M.E. Hatziolos. 2007. Coral reefs under rapid climate change and ocean acidification. Science 318:1737-1742.

Hughes, T.P., A.H. Baird, D.R. Bellwood, M. Card, S.R. Connolly, C. Folke, R. Grosberg, O. HoeghGuldberg, J.B.C. Jackson, J. Kleypas, J.M. Lough, P. Marshall, M. Nyström, S.R. Palumbi, J.M. Pandolfi, B. Rosen, and J. Roughgarden. 2003. Climate change, human impacts, and the resilience of coral reefs. Science 301:929-933.

International Union for Conservation of Nature (IUCN). 2001. IUCN Red List Categories and Criteria: Version 3.1. Gland, Switzerland and Cambridge, UK: IUCN Species Survival Commission.

Kenyon, J.C., R.E. Brainard, R.K. Hoeke, F.A. Parrish, and C.B. Wilkinson. 2006a. Towed-diver surveys, a method for mesoscale spatial assessment of benthic reef habitat: A case study at Midway Atoll in the Hawaiian Archipelago. Coast. Manage. 34(3):339-349.

Kenyon, J.C., M.J. Dunlap, and G.S. Aeby. 2008b. Community structure of hermatypic corals at Kure Atoll in the Northwestern Hawaiian Islands: Stemming the shifting baseline. Atoll Research Bulletin 559:1-27.

Kenyon, J.C., M.J. Dunlap, C.B. Wilkinson, K.N. Page, P.S. Vroom, and G.S. Aeby. 2007a. Community structure of hermatypic corals at Pearl and Hermes Atoll, Northwestern Hawaiian Islands: Unique conservation challenges in the Hawaiian Archipelago. Atoll Research. Bulletin 549:1-23.

Kenyon, J.C., P.S. Vroom, K.N. Page, M.J. Dunlap, C.B. Wilkinson, and G.S. Aeby. 2006b. Community structure of hermatypic corals at French Frigate Shoals, Northwestern Hawaiian Islands: Capacity for resistance and resilience to selective stressors. Pac. Sci. 60(2):151-173.

Kenyon, J.C., C.B.Wilkinson, and G.S. Aeby. 2008a. Community structure of hermatypic corals at Maro Reef in the Northwestern Hawaiian Islands: A unique open atoll. Atoll Research Bulletin 558: 124.

Kenyon, J.C., C.B. Wilkinson, M.J. Dunlap, G.S. Aeby, and C. Kryss. 2007b. Community structure of 
hermatypic corals at Laysan Island and Lisianski Island/Neva Shoal in the northwestern Hawaiian Islands: A new layer of scientific exploration. Atoll Research Bulletin 550:1-28.

Knowlton, N. 2001. The future of coral reefs. Proc. Natl. Acad. Sci. USA 98:5419-5425.

Kohler, K.E., and S.M. Gill. 2006. Coral Point Count with Excel extensions (CPCe): A Visual Basic program for the determination of coral and substrate coverage using random point count methodology. Computers \& Geosciences 32:1259-1269.

Lobel, P.S., and L.K. Lobel. 2004. Annotated checklist of the fishes of Wake Atoll. Pac. Sci. 58(1):6590.

. 2008. "Aspects of the biology and geomorphology of Johnston and Wake Atolls, Pacific Ocean." In Coral Reefs of the World, Volume 1: Coral Reefs of the USA., ed. B.M. Riegel and R.E. Dodge, pp. 655-690. New York: Springer.

Maragos, J.E. 1994. Description of reefs and corals for the 1988 protected area survey of the northern Marshall Islands. Atoll Research Bulletin 419:1-88 and appendices.

Maragos, J.E., D.C. Potts, G.S. Aeby, D. Gulko, J.C. Kenyon, D. Siciliano, and D. Vanravenswaay. 2004. 2000-2002 rapid ecological assessment of corals on the shallow reefs of the northwestern Hawaiian Islands. Part 1: Species and distribution. Pac. Sci. 58(2):211-230.

Mundy, C. 1996. A quantitative survey of the corals of American Samoa. Department of Marine and Wildlife Resources Biological Report Series. Pago Pago, American Samoa: Department of Marine and Wildlife Resources.

Olson, S. 1996. History and ornithological journals of the Tanager expedition of 1923 to the northwestern Hawaiian Islands, Johnston, and Wake Islands. Atoll Research Bulletin 433:1-210.

Pandolfi, J.M., J.B.C. Jackson, N. Baron, R.H. Bradbury, H.M. Guzman, T.P. Hughes, C.V. Kappel, F. Micheli, J.C. Ogden, H.P. Possingham, and E. Sala. 2005. Are U.S. coral reefs on the slippery slope to slime? Science 307:1725-1726.

Preskitt, L.B., P.S. Vroom, and C.M. Smith. 2004. A rapid ecological assessment (REA) quantitative survey method for benthic algae using photoquadrats with SCUBA. Pac. Sci. 58(2):201-209.

Randall, R.H. 2003. An annotated checklist of hydrozoan and scleractinian corals collected from Guam and other Mariana Islands. Micronesica 35-36:121-137.

Randall, R.H., and R.F. Myers. 1983. Guide to the coastal resources of Guam: Volume 2. The Corals. Mangilao, Guam: University of Guam Press.

Tsuda, R.T., J.R. Fisher, P.S. Vroom, and I. Abbott. 2010. New records of subtidal benthic marine algae from Wake Atoll, Central Pacific. Botanica Marina 53:19-29.

U.S. Fish and Wildlife Service. 1999. Baseline marine biological survey, Peacock Point outfall and other point-source discharges, Wake Atoll, Pacific Ocean. Honolulu: U.S. Department of Interior Fish and Wildlife Service.

Vargas-Ángel, B. 2009. Coral health and disease assessment in the U.S. Pacific territories and affiliated states. Proc. 11th Int. Coral Reef Symp., Ft. Lauderdale 175-179.

Veron, J.E.N. 2000. Corals of the world. Vols. 1-3., Townsville, Queensland, Australia: Australian Institute of Marine Science and CRR Qld. Pty Ltd.

Vroom, P.S., K.S. Page, K.A. Peyton, and J.K. Kukea-Shultz. 2005. Spatial heterogeneity of benthic community assemblages with an emphasis on reef algae at French Frigate Shoals, northwestern Hawaiian Islands. Coral Reefs 24:574-581.

Waddell, J.E., ed. 2005. The state of coral reef ecosystems of the United States and Pacific freely associated states: 2005. NOAA Technical Memorandum NOS NCCOS 11. NOAA/NCCOS Center for Coastal Monitoring and Assessment Biogeography Team. Silver Spring, Md.

Wilkes, C. 1844. Narrative of the U.S. exploring expedition during the years 1838-1842. Volume 5, Wake's Island. Philadelphia: Lea \& Blanchard.

Williams, I.D., B.L. Richards, S.A. Sandin, J.K. Baum, R.E. Schroeder, M.O. Nadon, B. Zgliczynski, P. Craig, J.L. Mcllwain, and R.E. Brainard. 2011. Differences in reef fish assemblages between populated and remote reefs spanning multiple archipelagos across the central and western Pacific. J. Marine Bio., 2011: Article ID 826234, doi:10.1155/2011/826234. 